\title{
Recent advances on the enantioselective synthesis of C-nucleosides inhibitors of inosine monophosphate dehydrogenase (IMPDH)
}

Pedro Merino, ${ }^{* a}$ Mattia Ghirardello, ${ }^{a}$ Tomás Tejero, ${ }^{\mathrm{a}}$ Ignacio Delso ${ }^{\mathrm{a}, \mathrm{b}}$ and Rosa Matute. ${ }^{\mathrm{c}}$

a Laboratorio de Síntesis Asimétrica. Departamento de Síntesis y Estructura de Biomoléculas. ISQCH.

Universidad de Zaragoza. CSIC. Campus San Francisco. Zaragoza, Aragón, Spain.

${ }^{\mathrm{b}}$ Servicio de Resonancia Magnetica Nuclear. CEQMA. Universidad de Zaragoza. CSIC. Campus San

Francisco. Zaragoza, Aragón, Spaín.

${ }^{c}$ Departamento de Ingeniería Química y Tecnologías del Medio Ambiente. Escuela Universitaria de Ingeniería Industrial. Edificio Torres Quevedo. Campus Actur. Zaragoza, Aragón, Spain.

Phone: +34 876 553783. E-mail: pmerino@unizar.es

\begin{abstract}
This review will describe the recent advances in the synthesis of C-nucleosides with inhibitory activity of inosine monophosphate dehydrogenase (IMPDH), a key enzyme in the biosynthesis of guanine nucleotides. The review will cover synthetic approaches of structural analogues showing modifications in the furanose ring as well as in the heterocyclic base. Heterocyclic sugar nucleoside analogues in which the furanose ring has been replaced by a different heterocyclic ring including aza analogues, thioanalogues as well as dioxolanyl and isoxazolidinyl analogues are also considered.
\end{abstract}

\section{Keywords}

C-Nucleosides / Enzyme inhibitors / Tiazofurin / Thiazole / IMPDH / Heterocyclic nucleosides

\section{Short Running Title}

C-Nucleosides inhibitors of IMPDH 


\section{Introduction}

Inosine monophosphate dehydrogenase (IMPDH) is a key enzyme in the biosynthesis of guanine nucleotides and, thus, pivotal for cell growth. In particular, it is the responsible of transforming inosine monophosphate (IMP) 1 into xanthosine monophosphate (XMP) 2, which is subsequently transformed into guanosine monophosphate (GMP) 3 by the action of GMP-synthetase (Scheme 1).<smiles>COP(=O)(OC)OCC1O[C@@H]2C(O)[C@H]1C(O)[C@H]2n1cnc2c(=O)[nH]cnc21</smiles>

1 (IMP)

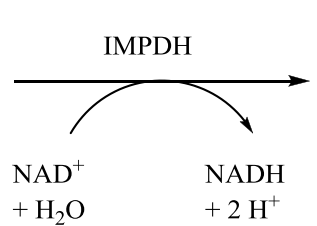

$+\mathrm{H}_{2} \mathrm{O}$

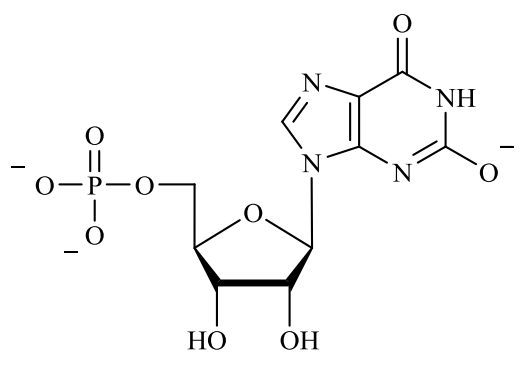

2 (XMP)
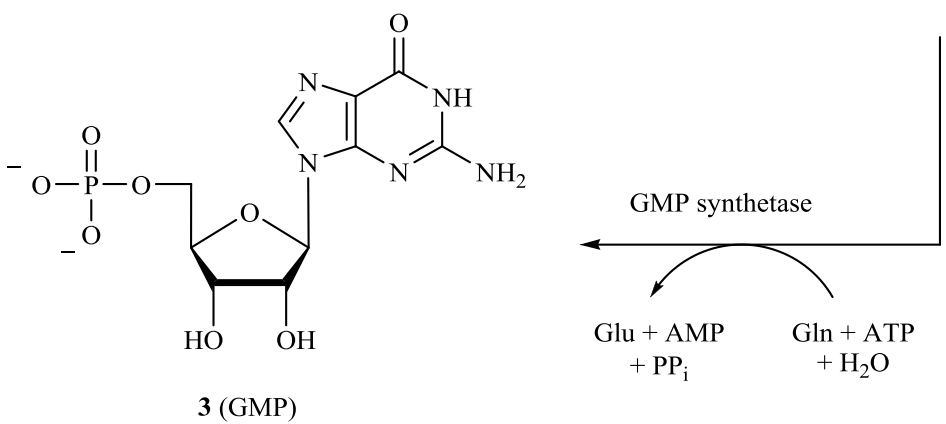

Scheme 1. Biosynthesis of guanine nucleotides

IMPDH was first suggested as a potential target for cancer chemotherapy by Weber and co-workers[1] after it was shown that the activity of IMPDH was amplified in a variety of tumors and rapidly proliferating tissues. The Biology of IMPDH including structure, mechanism and inhibition has been studied in detail [2] and several reviews have been focused on IMPDH as a drug target[3] in cancer, [4] antiviral,[5] immunosuppressive[6] and antimicrobial chemotherapy. [7]

Typically, there are two classes of IMPDH inhibitors, [8] i.e. non-nucleoside inhibitors such as mycophenolic acid (MPA) 4 and nucleoside inhibitors. Among the latter are mizoribine $\mathbf{5}$ and ribavirin 6. These nucleoside inhibitors produce IMPDH inhibition via their anabolite 5'-monophosphates. Whereas non-nucleoside inhibitors bind at the NAD site of the enzyme, the nucleoside analogues bind at the substrate site.[9] Nuclear magnetic resonance and molecular modeling studies on 4[10] indicated that MPA is capable of binding to the nicotinamide site of the enzyme mimicking the $\mathrm{NAD}^{+}$inverse regulation.[11] The mechanism of action of ribavirin has been studied in combination with interferon- $\alpha$ (IFN $\alpha$ ).[12] Crystal structure of IMPDH in complex with ribavirin demonstrates that $\mathbf{6}$ targets the substrate binding site.[13] 
<smiles>COc1c(C)c2c(c(O)c1C/C=C(\C)CCC(=O)O)C(=O)OC2</smiles>

4 (mycophenolic acid)

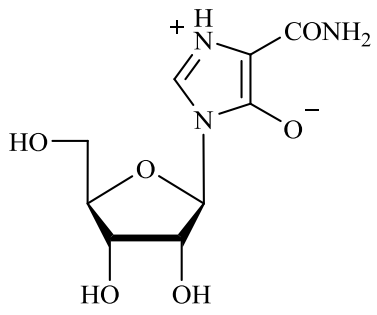

5 (mizoribine)<smiles>NC(=O)c1ncn(C2OC(CO)C(O)C2O)n1</smiles>

6 (ribavirin)

Figure 1. IMPDH inhibitors

$C$-nucleosides, like tiazofurin $\mathbf{7}$ or benzamide riboside 10, also inhibit IMPDH but through a different mechanism of action to that observed for $N$-nucleosides 5 and $\mathbf{6}$. Tiazofurin $\mathbf{7}$ inhibits IMPDH after its previous activation through phosphorylation and adenylation to form the corresponding dinucleotide TAD, 9 an analogue of NAD (Scheme 2). Similarly, benzamide riboside $\mathbf{1 0}$ is converted into the active metabolite BAD 11. [14] In fact, the identification of the active site of the enzyme [15] and selectivity studies with enzymes from different species,[16] confirmed that nicotinamide adenine dinucleotide (NAD) analogues containing $C$-nucleosides bind at the NAD site of IMPDH and, thus, they can act as competitive inhibitors of the enzyme.[17] In this respect the action of nicotinamide mononucleotide adenylyltransferase (NMNAT) is crucial since this enzyme is the responsible of catalyzing the metabolic conversion of tiazofurin (and its analogues) into its active form tiazofurin adenine dinucleotide (TAD).

[18] Notably, pyridine $C$-nucleosides such as $C$-nicotinamide riboside are not metabolized into the adenylated derivatives and thus, they do not exhibit any inhibitory activity.[19] 


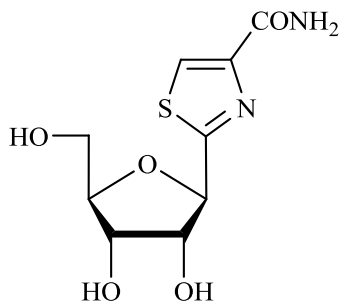

7 (tiazofurin)

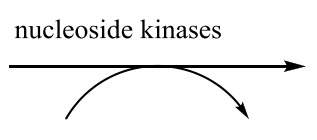

ATP

ADP<smiles>COP(=O)(O)OCC1OC(c2nc(C(N)=O)cs2)C(O)C1O</smiles>

8

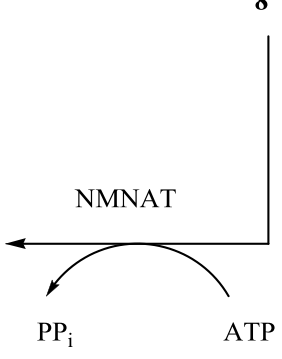<smiles>NC(=O)c1cccc(C2OC(CO)C(O)C2O)c1</smiles>

10 (benzamide riboside)<smiles>COP(=O)(O)OP(=O)([O-])OCC1OC2C(c3cccc(C(N)=O)c3)OC(C1O)C2O</smiles>

$11(\mathrm{BAD})$

Scheme 2. Activation of tiazofurin as IMPDH inhibitor

Due to the possibility of targeting both NAD- and substrate-binding sites there is a wide range of scaffolds suitable to be considered IMPDH inhibitors. [20] In particular, $C$-nucleosides have enormous potential in the development of novel IMPDH inhibitors and, consequently, a number of synthetic approaches have been developed towards their preparation. In this review, we focus our attention on $C$ nucleosides with different heterocyclic units linked to the ribose moiety. The members of this family of compounds are considered analogues of tiazofurin $\mathbf{7}$ and in addition to such product include: i) twoheteroatom containing heterocyclic analogues (selenazofurin 12, oxazofurin 13 and imidazofurin 14), and ii) one-heteroatom containing heterocyclic analogues (thiophenfurin 15, selenophenfurin 16 and furanfurin 17). Also, $C$-nucleosides in which the ribose moiety has been replaced by a different heterocyclic ring - the so-called heterocyclic-sugar nucleoside analogues-[21] will be discussed. Among these compounds are aza-tiazofurin 18, thionucleosides 19-21, dioxolanyl tiazofurin 22 and isoxazolidinyl nucleosides 23 and 24 (Figure 2). 


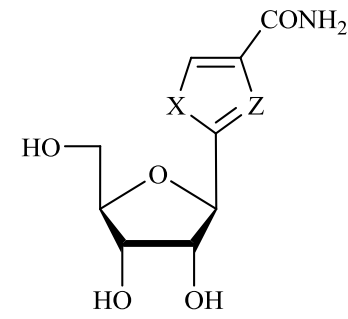

$12 \mathrm{X}=\mathrm{Se} \quad \mathrm{Z}=\mathrm{N} \quad$ (selenazofurin)

$13 \mathrm{X}=\mathrm{O} \quad \mathrm{Z}=\mathrm{N} \quad$ (oxazofurin)

$14 \quad \mathrm{X}=\mathrm{NH} \quad \mathrm{Z}=\mathrm{N} \quad$ (imidazofurin)

$15 \mathrm{X}=\mathrm{S} \quad \mathrm{Z}=\mathrm{CH} \quad$ (thiophenfurin)

$16 \mathrm{X}=\mathrm{Se} \quad \mathrm{Z}=\mathrm{CH} \quad$ (selenophenfurin)

$17 \mathrm{X}=\mathrm{O} \quad \mathrm{Z}=\mathrm{CH} \quad$ (furanfurin)

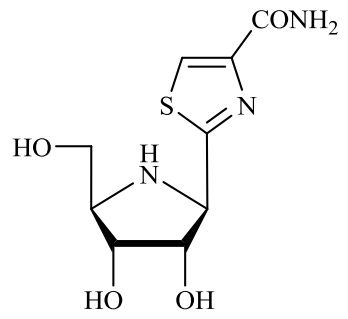

18 (azatiofurin)

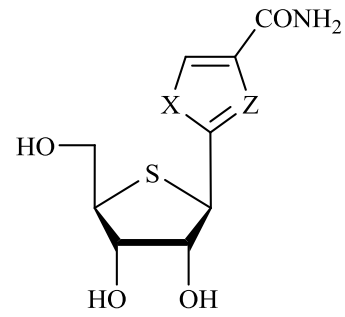

$19 \mathrm{X}=\mathrm{S} \quad \mathrm{Z}=\mathrm{N} \quad$ (thiotiazofurin)

$20 \mathrm{X}=\mathrm{S} \quad \mathrm{Z}=\mathrm{CH}$ (thiophenthiofurin)

$21 \mathrm{X}=\mathrm{O} \quad \mathrm{Z}=\mathrm{CH} \quad$ (furanthiofurin)

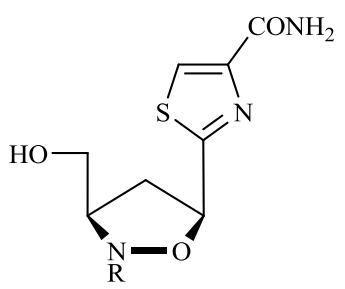

23

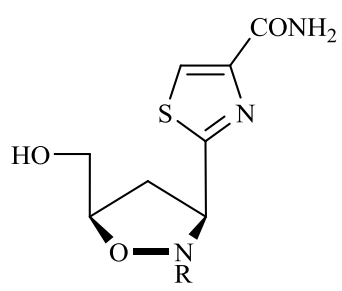

24

Figure 2. Tiazofurin analogues

The chemical synthesis of nucleoside analogues is a subject of interest in the framework of medicinal chemistry. [22] Although several reviews have been reported elsewhere regarding the biological activity of compounds 7 and 12-23, [7-8,23] chemical synthesis is only discussed partially.[17,24] This review provides the reader with an overview of the chemical synthesis of those $C$-nucleosides. In the case of tiazofurin and their pentose-containing analogues only methodologies developed during the last decade will be considered.

\section{Tiazofurin and sugar-containing analogues}

Tiazofurin was first synthesized by Robins and co-workers in 1977. [25] Since then, several synthetic approaches have been reported, [26] most of them based on construction of the thiazole ring by cyclocondensation of cysteine ethyl ester $\mathbf{2 8}$ with a sugar-derived nitrile $\mathbf{2 7}$, further oxidation of the resulting $\Delta^{2}$-thiazoline $\mathbf{2 6}$, deprotection and transformation of the ester $\mathbf{2 5}$ into the amide moiety as illustrated in the retrosynthetic analysis depicted in Scheme 3. 


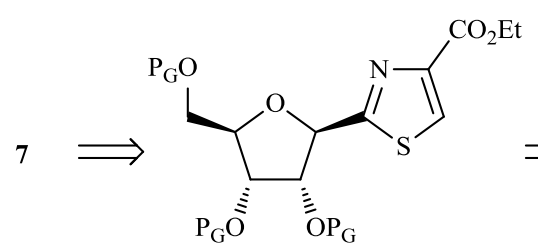

25<smiles>C=C</smiles>

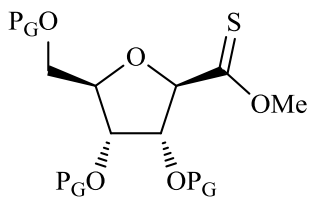

29<smiles>CCOC(=O)C(N)C#N</smiles>

30

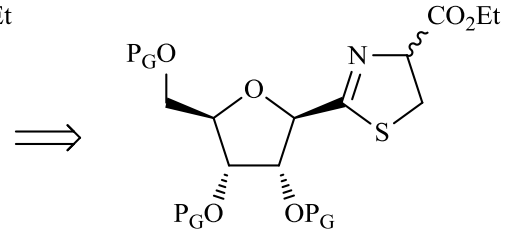

26

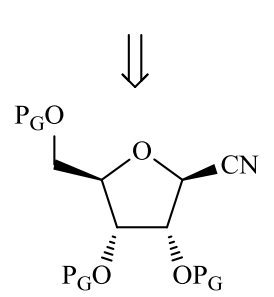

27<smiles>CCOC(=O)[C@H](N)C[SiH3]</smiles>

28

Scheme 3. Retrosynthetic analysis of tiazofurin

An inherent problem to this general approach is the oxidation step of intermediate 26, which depending on the oxidation conditions can lead to undesired furan-derived byproducts. Also, in this approach the use of toxic oxidants like mercury salts should be avoided.

Alternatively, the thiazole ring can also be constructed from the corresponding thioester 29 by condensation with ethyl-2-amino-2-cyanoacetate (30) with subsequent elimination of the resulting amino group at C-5 of the thiazole ring. [27] However, this approach involves the use of hydrogen sulfide which is environmentally unsafe when used on large-scale production.

Ramasamy and co-workers reported [26,28] the synthesis of tiazofurin 7 starting from 1-cyano protected D-ribose (31) (Scheme 4). Condensation with $\mathbf{2 8}$ afforded thiazole $\mathbf{3 2}$ which was successfully oxidized with manganese (IV) oxide to give 33. Further deprotection of the hydroxyl group and treatment with methanolic ammonia afforded tiazofurin 7 in $79 \%$ overall yield from 31. The methodology did not required chromatographic purification therefore being highly suitable for large scale preparation. 
<smiles>CC1(C)O[C@H]2[C@@H](CO)O[C@@H](C#N)[C@H]2O1</smiles>

31

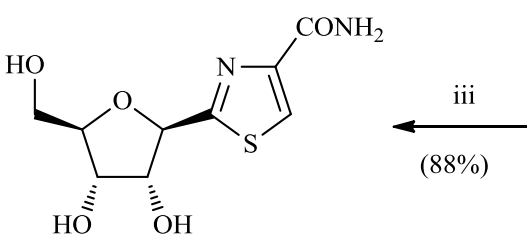

7

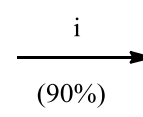

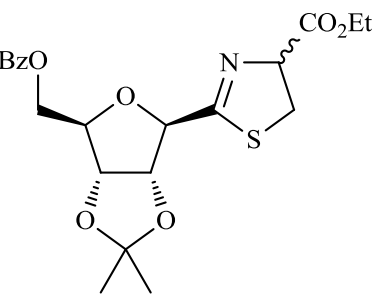

32

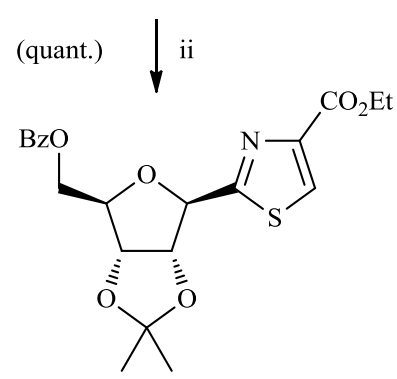

33

Scheme 4. Reagents and conditions: (i) $28 \cdot \mathrm{HCl}, \mathrm{Et}_{3} \mathrm{~N}$. (ii) $\mathrm{MnO}_{2}$, benzene, reflux. (iii) $90 \% \mathrm{TFA}$, then $\mathrm{MeOH}, \mathrm{NH}_{3}$.

The same approach was employed by Dowden and co-workers [29] who started from the tri- $O$ benzoylateD-1-cyano-D-ribose $\mathbf{3 4}$ thus avoiding the final deprotection step since benzoyl groups are eliminated simultaneously during the conversion of the ester moiety into the amide function (Scheme 5). The oxidation step was carried out with bromotrichloromethane in the presence of DBU.

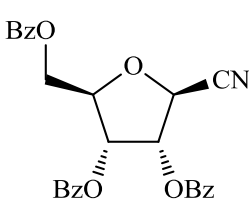

34

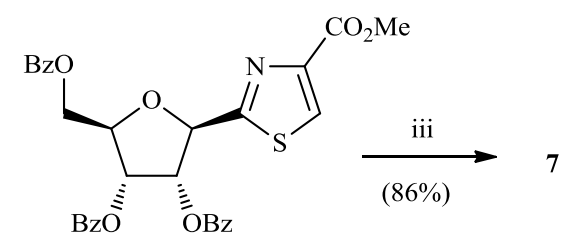

35

Scheme 5. Reagents and conditions: (i) $28 \cdot \mathrm{HCl}, \mathrm{Et}_{3} \mathrm{~N}$. (ii) $\mathrm{BrCCl}_{3}, \mathrm{DBU}, \mathrm{CH}_{2} \mathrm{Cl}_{2}, 0^{\circ} \mathrm{C}$. (iii) $\mathrm{MeOH}, \mathrm{NH}_{3}$, rt, $20 \mathrm{~h}$.

The lack of specifity and cytoxycity found for tiazofurin during phase II and III clinical trials [30] prompted the search of structural analogues, especially those with variations in the furanose ring. In this context, analogues with xylo [31] and arabino configurations have been prepared [32] and their structural features studied. [33]

Also 5'-, [25,34] 3'- [35] and 2'-substituted [36] derivatives have been reported but none showed significant biological activity. On the other hand, Popsavin and co-workers reported [37] a divergent synthesis of 3'-fluoro and 3'-acetamido analogues $\mathbf{4 3}$ and $\mathbf{4 4}$ from intermediate $\mathbf{3 6}$-easily available from D-glucose-, [38] which showed potent cytotoxic activity against leukemia and colon adenocarcinoma. The synthetic approach illustrated in Scheme 6 is based on the formation of the corresponding anomeric cyanides 39 and $\mathbf{4 0}$. The construction of the thiazole ring was made through the Hantzsch's condensation of thioamides 41 and $\mathbf{4 2}$ with ethyl bromopyruvate. 
<smiles>OC[C@H]1O[C@@H](C2OCCO2)[C@H]([18OH])[C@@H]1O</smiles>

36

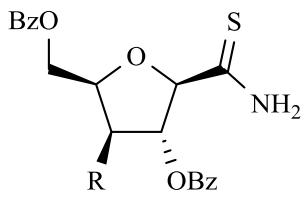

$41 \mathrm{R}=\mathrm{F} \quad$ (89\%)

$42 \mathrm{R}=\mathrm{NHAc}(81 \%)$

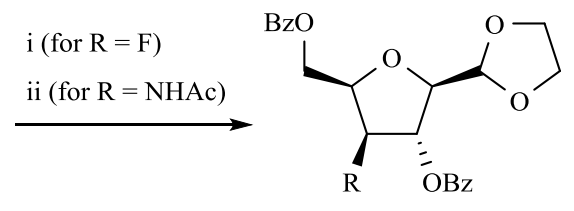

$37 \quad \mathrm{R}=\mathrm{F} \quad(68 \%)$

$38 \mathrm{R}=$ NHAc $(70 \%)$

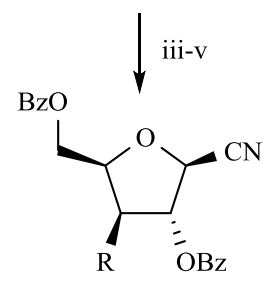

$39 \quad \mathrm{R}=\mathrm{F} \quad(59 \%)$

$40 \mathrm{R}=\mathrm{NHAc}(77 \%)$<smiles>[R]NC(=O)N[R]</smiles>

Scheme 6. Reagents and conditions: (i) $\mathrm{Bu}_{4} \mathrm{NF}, \mathrm{THF},-18^{\circ} \mathrm{C}, 22 \mathrm{~h}$. (ii) $\mathrm{NaN}_{3}, \mathrm{DMSO}, \mathrm{THF}, \mathrm{rt}, 24 \mathrm{~h}$ then $\mathrm{PtO}_{2}, \mathrm{Ac}_{2} \mathrm{O}, \mathrm{AcOH}, \mathrm{rt}, 21$ h. (iii) 9:1 TFA-6M HCl, $4^{\circ} \mathrm{C}, 6$ days. (iv) $\mathrm{NH}_{2} \mathrm{OH} \cdot \mathrm{HCl}, \mathrm{NaOAc}, \mathrm{EtOH}, \mathrm{rt}, 2 \mathrm{~h}$. (v) $\mathrm{MsCl}, \mathrm{Py},-15^{\circ} \mathrm{C}, 1.5$ h. (vi) $\mathrm{H}_{2} \mathrm{~S}$, DMAP, EtOH, rt, 4 h. (vii) $\mathrm{BrCH}_{2} \mathrm{COCO}_{2} \mathrm{Et}, \mathrm{EtOH}, 80^{\circ} \mathrm{C}, 50 \mathrm{~min}$. (viii) $\mathrm{NH}_{3}, \mathrm{MeOH}$, rt, 8 days.

The same authors reported [39] the synthesis of analogues $\mathbf{4 6}$ and $\mathbf{4 7}$ by using the same methodology and starting from 2-azido derivative 45 (Scheme 7). Structural analogues 49 and 50 with hexan- and dodecanamido fuctionalities at C2' have also been synthesized from 48 [40] and 3'-amino xylo derivative 52 from 51. [41] 
<smiles>N[C@@H]1[C@H](O)[C@@H](CO)O[C@H]1C1OCCO1</smiles>

45<smiles>COC[C@H]1O[C@@H](C2OCCO2)[C@H](O)[C@@H]1O</smiles>

48<smiles>N[C@@H]1[C@@H](CC(=O)O)O[C@@H](C2OCCO2)[C@@H]1[18OH]</smiles>

51<smiles>CO[C@H]1[C@@H](COC(=O)c2ccccc2)O[C@H](C2OCCO2)[C@@H]1OC(=O)c1ccccc1</smiles>

53

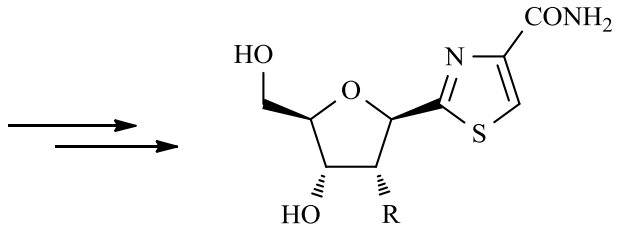

$46 \mathrm{R}=\mathrm{NHBz}$ (overall 8 steps: $12.9 \%$ )

$47 \mathrm{R}=\mathrm{N}_{3} \quad$ (overall 7 steps: $5.7 \%$ )

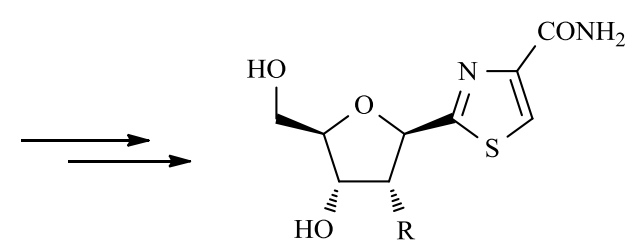

$49 \mathrm{R}=\mathrm{NHCOC}_{5} \mathrm{H}_{11} \quad$ (overall 8 steps: $5.6 \%$ )

$50 \mathrm{R}=\mathrm{NHCOC}_{11} \mathrm{H}_{23}$ (overall 8 steps: $5.0 \%$ )

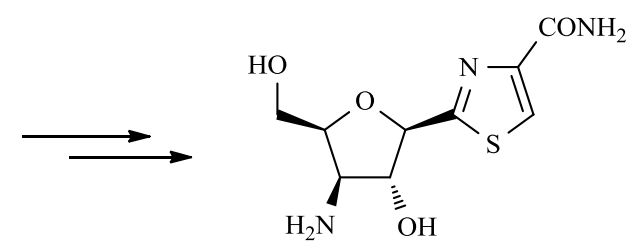

52 (overall 8 steps: $2.6 \%$ )

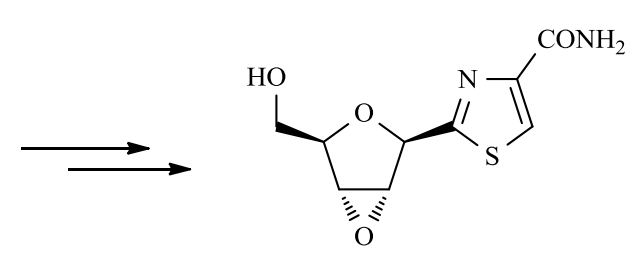

54 (overall 6 steps: $13.9 \%)$

Scheme 7. Synthesis of tiazofurin analogues

2',3'-Anhidro tiazofurin $\mathbf{5 4}$ was synthesized from $\mathbf{5 3}$ in 6 steps and 13.9 overall yield. [42] Starting from aldehyde $\mathbf{5 5}$-easily available from $\mathbf{5 3}$ by acidic hydrolysis- the homologated cyanide $\mathbf{5 6}$ was prepared in three steps and $47 \%$ overall yield. After formation of thioamide $\mathbf{5 7}$ the condensation with ethyl bromo pyruvate afforded a 3:2 mixture of anomers 58, Methanolic ammoniolysis of these isomers furnished in one step the homologated anhydro analogues $\mathbf{5 9}$ (Scheme 8). [43] 


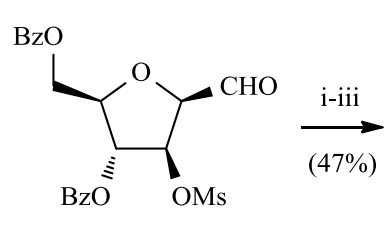

55

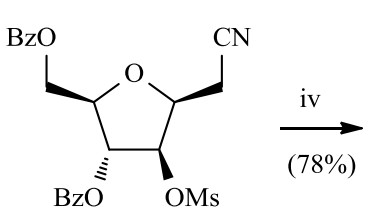

56

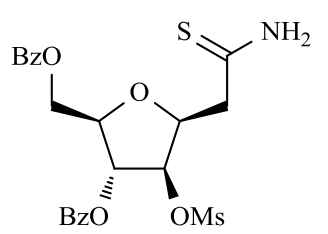

57<smiles>[R6]OC[C@H]1O[C@H](Cc2nc(C(=O)OCC)cs2)[C@H](OC(=O)c2ccccc2)[C@@H]1O</smiles>

$58 a$

vi $\downarrow(60 \%)$<smiles>NC(=O)c1csc(C[C@H]2O[C@H](CO)[C@H]3O[C@@H]23)n1</smiles>

$59 a$

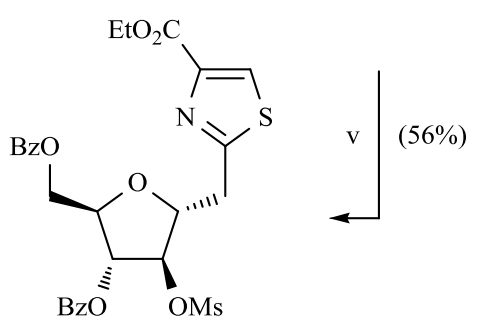

$58 b$

vi $\downarrow(65 \%)$

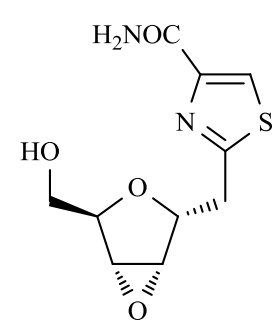

59b

Scheme 8. Reagents and conditions: (i) $\mathrm{NaBH}_{4}, \mathrm{MeOH}, 0^{\circ} \mathrm{C}, 40 \mathrm{~min}$, then $\mathrm{rt}, 40$ min. (ii) $\mathrm{Tf}_{2} \mathrm{O}, \mathrm{Py}$, $\mathrm{CH}_{2} \mathrm{Cl}_{2},-10{ }^{\circ} \mathrm{C}, 0.5 \mathrm{~h}$, then rt, 0.5 h. (iii) $\mathrm{NaCN}$, DMF, rt, 1.5 h. (iv) $\mathrm{H}_{2} \mathrm{~S}, \mathrm{Py}$, rt, 14 days. (v) $\mathrm{BrCH}_{2} \mathrm{COCO}_{2} \mathrm{Et}$, EtOH, $80^{\circ} \mathrm{C}, 50 \mathrm{~min}$. (vi) $\mathrm{NH}_{3}, \mathrm{MeOH}$, rt, 8 days.

Starting from diacetone-D-glucose, Chun and co-workers reported [44] the synthesis of key intermediate $\mathbf{6 0}$ in 9 steps and 15\% overall yield (Scheme 9). Further construction of the thiazole ring was carried out through condensation with L-cysteine ethyl ester hydrochloride followed by oxidation with bromotrichloromethane in DBU. Concomitant ammoniolysis of benzoyl esters and formation of the amide group furnished azido analogue $\mathbf{6 1}$ which upon hydrogenation at atmospheric pressure provided the 3'amino derivative 62 (Scheme 9). 
<smiles>CC1(C)OC[C@H]([C@H]2O[C@@H]3OC(C)(C)O[C@@H]3[C@H]2O)O1</smiles>

diacetone D-glucose<smiles>NC(=O)c1csc([C@@H]2O[C@H](CO)[C@@H](N)[C@H]2O)n1</smiles>

62

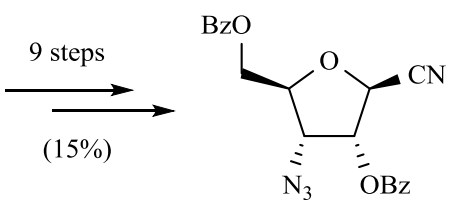

60

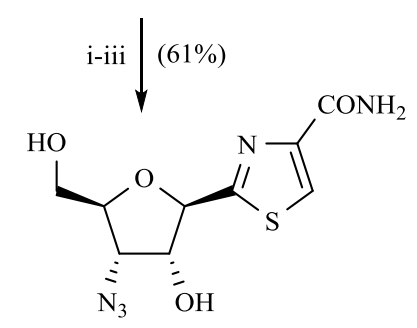

61

Scheme 9. Reagents and conditions: (i) 28. $\mathrm{HCl}, \mathrm{Et}_{3} \mathrm{~N}, \mathrm{MeOH}, \mathrm{rt}, 2 \mathrm{~h}$. (ii) $\mathrm{BrCCl}_{3}, \mathrm{DBU}, \mathrm{CH}_{2} \mathrm{Cl}_{2}, 0^{\circ} \mathrm{C}, 16$ h. (iii) $\mathrm{MeOH}, \mathrm{NH}_{3}, \mathrm{rt}, 24$ h. (iv) $\mathrm{H}_{2}$, PD-C, EtOH, rt, 14 h.

The 3'-deoxy-3'-hydroxymethyl branched derivative 67 was prepared by Chu and co-workers [45] from hydroxymethyl sugar 63, easily available from D-xylose. [46] After obtention of tri- $O$-benzoyl derivative 64 through conventional carbohydrate chemistry the cyano group was installed at the anomeric position by reaction of trimethylsilyl cyanide with the corresponding 1-acetoxy derivative $\mathbf{6 5}$. The construction of the thiazole ring was achieved as usual by reaction with L-cysteine and using bromotrichloromethane in DBU as oxidizing system of the intermediate oxazoline (Scheme 10). [45]

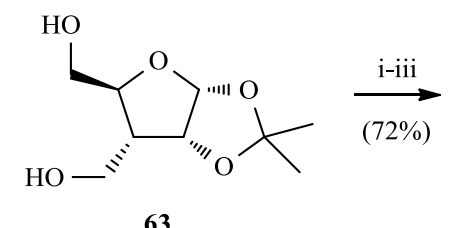

63

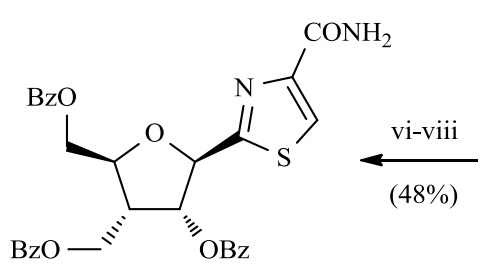

67

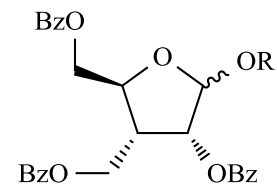

$64 \mathrm{R}=\mathrm{OMe}$
$65 \mathrm{R}=\mathrm{OAc} \longleftrightarrow$ iv $(95 \%)$

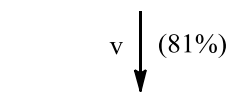

66

Scheme 10. Reagents and conditions: (i) $\mathrm{BzCl}$, pyridine, rt, $16 \mathrm{~h}$. (ii) $1 \% \mathrm{HCl}$ in $\mathrm{MeOH}, \mathrm{rt}, 3 \mathrm{~h}$. (iii) $\mathrm{BzCl}$, pyridine, rt, 16 h. (iv) $\mathrm{AcOH} / \mathrm{Ac}_{2} \mathrm{O} / \mathrm{H}_{2} \mathrm{SO}_{4}, 0{ }^{\circ} \mathrm{C}, 0.5$ h. (v) TMSCN, $\mathrm{SnCl}_{4}, \mathrm{CH}_{2} \mathrm{Cl}_{2}$, reflux, 3 h. (vi) L-cysteine ethyl ester hydrochloride, $\mathrm{Et}_{3} \mathrm{~N}, \mathrm{MeOH}, 2$ h. (vii) $\mathrm{DBU}, \mathrm{BrCCl}_{3}, \mathrm{CH}_{2} \mathrm{Cl}_{2}, 0^{\circ} \mathrm{C}, 16 \mathrm{~h}$. (viii) $\mathrm{NH}_{3} / \mathrm{MeOH}, \mathrm{RT}, 18 \mathrm{~h}$.

The isodedoxy analogue of tiazofurin has been prepared from dideoxyribose 68 (Scheme 11). [47] Reaction of 68 with potassium cyanide afforded nitrile 69 which was transformed into thioamide 70 by 
the action of hydrogen sulfide. Condensation of $\mathbf{7 0}$ with ethyl bromopyruvate and treatment with methanolic ammonia afforded the analogue $\mathbf{7 1 .}$<smiles>[18O]C[C@H]1C[C@@H]([18OH])CO1</smiles>

68

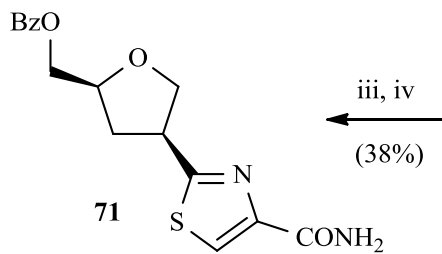

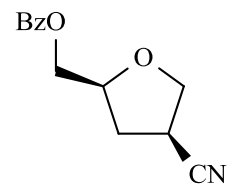

69

ii $\downarrow(58 \%)$

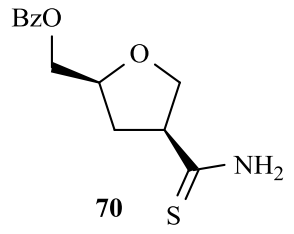

Scheme 11. Reagents and conditions: (i) KCN, [18]-crown-6, DMF, 24 h, $95^{\circ}$. (ii) $\mathrm{H}_{2} \mathrm{~S}, \mathrm{EtOH}, \mathrm{Et}_{3} \mathrm{~N}, 8 \mathrm{~h}$. (iii) $\mathrm{BrCH}_{2} \mathrm{COCO}_{2} \mathrm{Et}$, EtOH, reflux. (iv) $\mathrm{NH}_{3}, \mathrm{MeOH}$.

Other sugar-analogues of tiazofurin including acyclic, [48] oxetane [49] and pyranosyl [50] derivatives have also been reported in the past but either low chemical yields were obtained in their synthesis or no significant biological activity was found.

A similar approach to that employed for preparing tiazofurin and analogues with structural modifications in the furanose ring can be employed in the synthesis of analogues with heteroatoms different from sulfur in the heterocyclic base. As an example, the reaction of known imidate $\mathbf{7 2}$ with hydrogen selenide furnished methyl selenoate $\mathbf{7 3}$. Condensation of $\mathbf{7 3}$ with ethyl 2-amino-2-cyanoacetate 30 afforded intermediate $\mathbf{7 4}$, which was further converted into selenazofurin 12 through elimination of the amino group and formation of the amide functionality (Scheme 12). [51]<smiles>COC(=N)[C@H]1O[C@H](CO)[C@@H](O)[C@H]1O</smiles>

72<smiles>NC(=O)c1c[se]c([C@@H]2O[C@H](CO)[C@@H](O)[C@H]2O)n1</smiles>

12

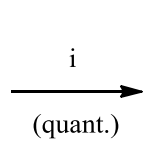

$\mathrm{HO}$

$\mathrm{HO}$<smiles>COC(=[Se])[C@H]1O[C@H](CO)[C@@H](O)[C@H]1O</smiles><smiles>CCOC(=O)c1nc([C@@H]2O[C@H](CO)[C@@H](O)[C@H]2O)sc1N</smiles>

74

Scheme 12. Reagents and conditions: (i) $\mathrm{H}_{2} \mathrm{Se}, \mathrm{MeOH}$, Dowex-50W-X8, $-22^{\circ} \mathrm{C}$. (ii) $\mathbf{3 0}, \mathrm{MeOH}, \mathrm{rt}, 30$ min. (iii) 18:12:31 $\mathrm{HCl}-\mathrm{H}_{2} \mathrm{O}-50 \% \mathrm{H}_{3} \mathrm{PO}_{4}, \mathrm{NaNO}_{2}, 0^{\circ} \mathrm{C}$ to rt, $1 \mathrm{~h}$. (iv) $\mathrm{NH}_{3}, \mathrm{MeOH}, 22^{\circ} \mathrm{C}, 24 \mathrm{~h}$.

Oxazofurin $\mathbf{1 3}$ was prepared by condensation of $\mathbf{3 0}$ with acyl chloride $\mathbf{7 5}$ in pyridine and further aciD-induced cyclization to provide intermediate $\mathbf{7 6}$. Compound $\mathbf{7 6}$ was obtained in only $12 \%$ yield due to the formation of undesired elimination products in both condensation and cyclization steps. 
Elimination of the amino group of the oxazole ring was carried out over protected 76 to give 77. Finally, deprotection of the benzoyl groups and formation of the amide furnished the target analogue $\mathbf{1 3}$ in 5 steps and $4.6 \%$ overall yield (Scheme 13). [52]<smiles>O=C(OC[C@H]1O[C@H](C(=O)Cl)[C@@H](OC(=O)c2ccccc2)[C@@H]1O)c1ccccc1</smiles>

75<smiles>NC(=O)c1coc([C@@H]2O[C@H](CO)[C@@H](O)[C@H]2O)n1</smiles>

13<smiles>CCOC(=O)c1nc([C@@H]2O[C@H](COCc3ccccc3)[C@@H](OC(C)C)[C@H]2O)oc1N</smiles>

76<smiles>CCOC(=O)c1coc([C@@H]2O[C@H](COC(=O)c3ccccc3)[C@@H](OC(=O)c3ccccc3)[C@H]2O)n1</smiles>

77

Scheme 13. Reagents and conditions: (i) 30, pyridine, rt, $3 \mathrm{~h}$. (ii) $\mathrm{HCl}$ (g), dry acetone, $4^{\circ} \mathrm{C}, 22 \mathrm{~h}$ (iii) $\mathrm{HCl}-\mathrm{H}_{2} \mathrm{O}-50 \% \mathrm{H}_{3} \mathrm{PO}_{4}, \mathrm{NaNO}_{2},-20^{\circ} \mathrm{C}, 4$ h. (iv) $10 \% \mathrm{NH}_{4} \mathrm{OH}, \mathrm{rt}, 6.5 \mathrm{~h}$.

A more expeditious synthesis of $\mathbf{1 3}$ was achieved through the reaction of nitrile $\mathbf{3 4}$ with ethyl $\alpha$ formyldiazoacetate $\mathbf{7 8}$ in the presence of rhodium (II) acetate. However, also in this case, the yield of the reaction was considerably low and other reaction conditions did not improve the result. Concomitant amide formation and deprotection in $\mathbf{7 9}$ provided oxazofurin $\mathbf{1 3}$ in 2 steps but $6.5 \%$ overall yield (Scheme 14). [53]<smiles>N#C[C@@H]1O[C@H](CO)[C@@H](O)[C@H]1OC(=O)c1ccccc1</smiles>

34<smiles>CCOC(=O)C(=N)C=O</smiles><smiles>NC(=O)c1coc([C@@H]2O[C@H](CO)[C@@H](O)[C@H]2O)n1</smiles>

13<smiles>CCOC(=O)c1coc([C@@H]2O[C@H](COC(=O)c3ccccc3)[C@@H](O)[C@H]2OC(=O)c2ccccc2)n1</smiles>

79

Scheme 14. Reagents and conditions: (i) $\mathrm{Rh}(\mathrm{OAc})_{2}, 85^{\circ} \mathrm{C}, 15$ h. (ii) $\mathrm{NH}_{3}, \mathrm{EtOH}, \mathrm{rt}, 35 \mathrm{~h}$.

Imidazofurin 14 was obtained in two steps from imidate 72. [54] Condensation of 72 with 2-amino3,3-diethoxypropionate hydrochloride $\mathbf{8 0}$ gave a mixture of the desired product $\mathbf{8 1}$ and byproduct $\mathbf{8 2}$ (Scheme 15). Treatment of this mixture with methanolic ammonia and further chromatographic separation furnished 14 in $30.6 \%$ overall yield ( 2 steps). The obtention of byproducts could be avoided by working with protected ( $O$-benzylated) products. Under such conditions imidazofurin $\mathbf{1 4}$ was obtained in $35 \%$ overall yield. 

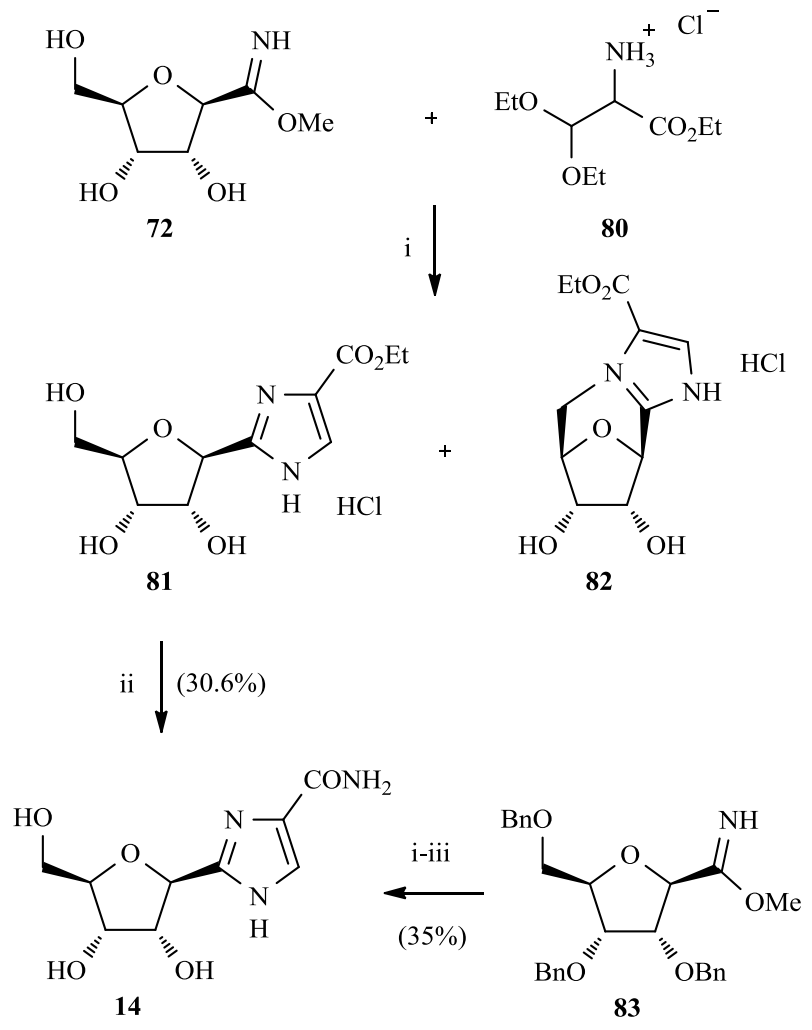

Scheme 15. Reagents and conditions: (i) anh. $\mathrm{MeOH}, \mathrm{rt}, 27 \mathrm{~h}$. (ii) $\mathrm{NH}_{3}, \mathrm{MeOH}, \mathrm{rt}, 6.5 \mathrm{~h}$. (iii) PD-C, $\mathrm{HCOONH}_{4}, \mathrm{MeOH}$, reflux, 1.5 .

The synthesis of pyrazole-containing derivatives have also been described. Treatment of glycosyl enaminone 84, easily available from D-ribose, [55] with semicarbazide hydrochloride afforded $\beta$-Dribofuranosyl pyrazole $\mathbf{8 5}$ in 51\% chemical yield. Any attempt of deprotecting benzoyl groups in $\mathbf{8 5}$ also led to decarbamoylation of the pyrazole ring and thus, the deprotected pyrazole analogue could not be obtained. On the other hand, acidic hydrolysis of $\mathbf{8 4}$ furnished $\mathbf{8 6}$ which upon reaction with semicarbazide hydrochloride led to 87. Cyclization of this compound in TFA and further deprotection with $10 \%$ aqueous ammonia furnished the analogue $\mathbf{8 8}$ in $25 \%$ overall yield (4 steps from 84) (Scheme 16). [56] 


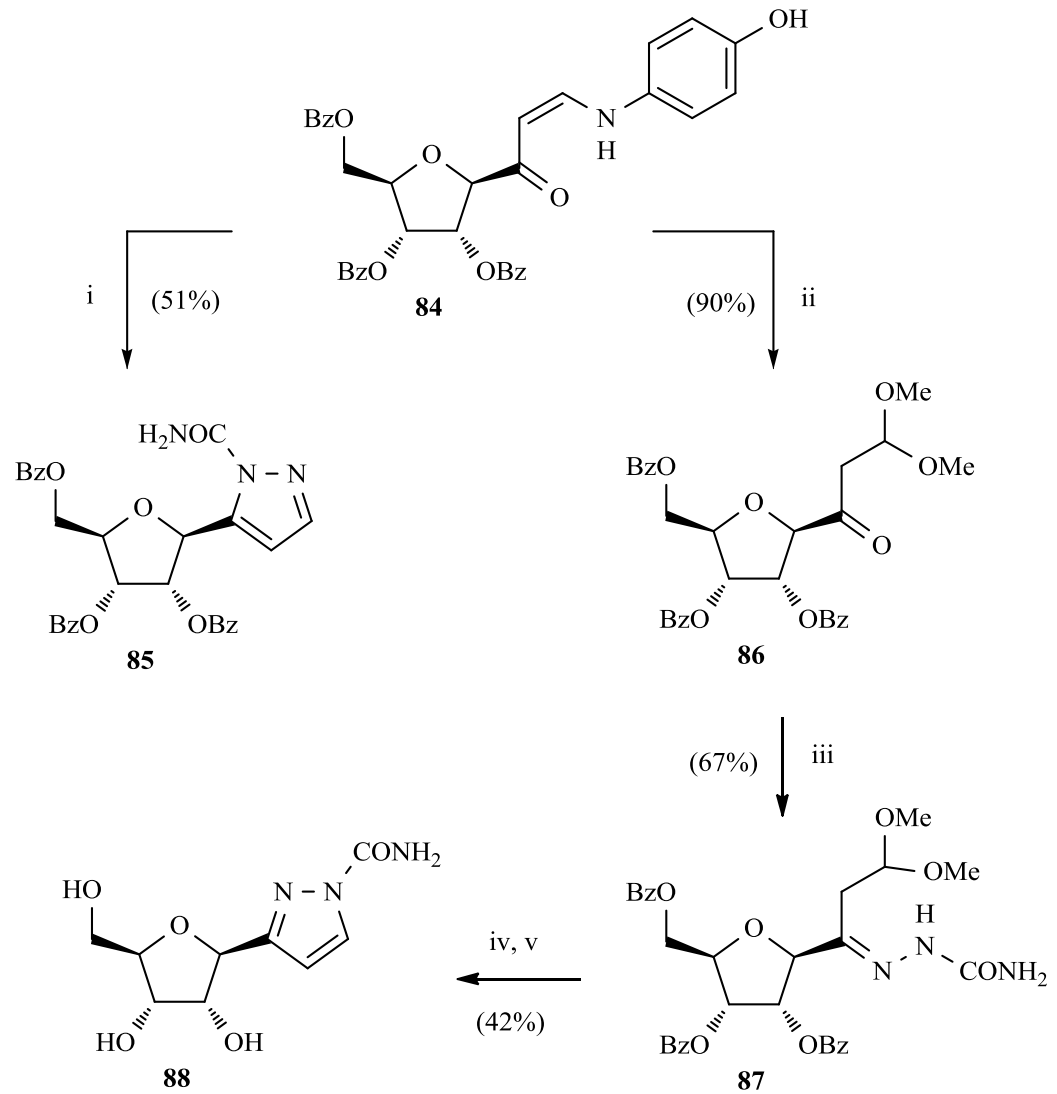

Scheme 16. Reagents and conditions: (i) dioxane, $\mathrm{NH}_{2} \mathrm{NHCONH}_{2} \cdot \mathrm{HCl}$, r.t., 4 days. (ii)

$\mathrm{MeOH}, \mathrm{HCl}$, r.t., 15 h. (iii) $\mathrm{EtOH}, \mathrm{NH}_{2} \mathrm{NHCONH}_{2} \cdot \mathrm{HCl}$, r.t., 5 h. (iv) TFA, r.t., 30 min. (v) aq $\mathrm{NH}_{4} \mathrm{OH}$, refrigerator, 3 days.

Tiazofurin analogues containing one heteroatom in the base moiety, i.e. thiophenfurin 15, selenophenfurin $\mathbf{1 6}$ and furanfurin $\mathbf{1 7}$ can be accessed following the same approach. Franchetti and coworkers reported [57] the condensation of the corresponding 3-(ethoxycarbonyl) heterocycle with tetra- $O$ acetyl- $\beta$-D-ribofuranose in the presence of tin (IV) chloride. The reaction afforded 2- and 5-regioisomers as mixture of $\alpha$ and $\beta$ anomers. [58] After chromatographic separation of the desired isomer the benzoyl groups were removed with sodium ethoxide in ethanol and the ester functionality transformed into the amide by treatment with $30 \%$ aqueous ammonium hydroxide (Scheme 17).<smiles>CC(=O)OCC1OC(OC(C)=O)[C@H](O[Na])[C@H]1O</smiles>

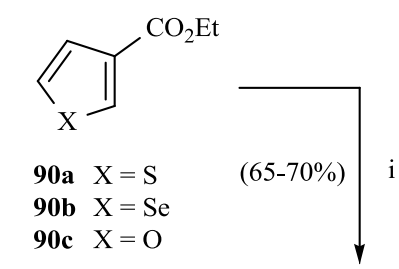<smiles>NC(=O)c1c[Y]c([C@@H]2O[C@H](CO)[C@@H](O)[C@H]2O)c1</smiles><smiles>CCOC(=O)c1c[Y]c(C2OC(CO)[C@@H]3O[C@@H](C(=O)OCC)[C@@H]3O2)c1</smiles>

91a $\mathrm{X}=\mathrm{S}$

91b $\mathrm{X}=\mathrm{Se}$

91c $\mathrm{X}=\mathrm{O}$ 
Scheme 17. Reagents and conditions: (i) $\mathrm{SnCl}_{4}$, 1,2-dichloroethane. (ii) $\mathrm{NaOEt}$, EtOH. (iii) $30 \% \mathrm{NH}_{4} \mathrm{OH}$.

Other analogues containing disubstituted amides at the heterocyclic ring have been prepared in the case of furanfurin. [59] Analogues 15-17 have also been employed for preparing the corresponding dinucleotides, isosteric NAD analogues. [60] The synthesis was carried out by imidazole-catalyzed coupling of the corresponding monophosphates with AMP (Scheme 18)

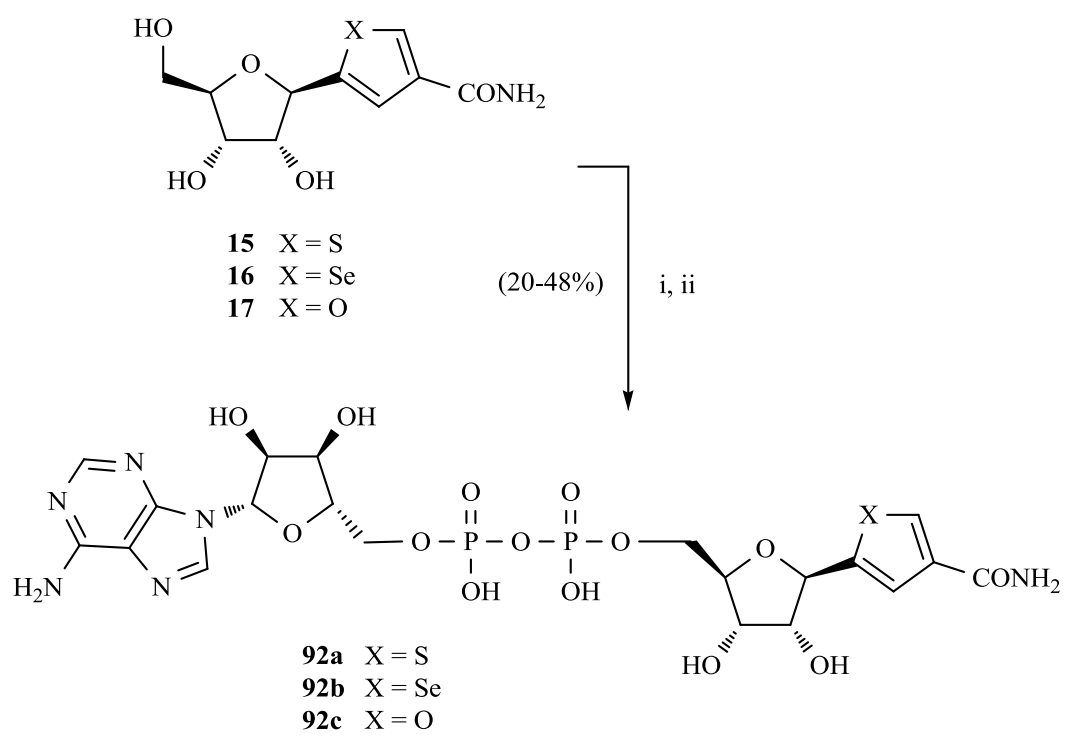

Scheme 18. Reagents and conditions: (i) $\mathrm{POCl}_{3},(\mathrm{MeO})_{3} \mathrm{PO}, \mathrm{H}_{2} \mathrm{O}, 10^{\circ} \mathrm{C}, 14 \mathrm{~h}$ then $2 \mathrm{M}$ TEAB. (ii) AMP, carbonyldiimidazole, $\mathrm{Bu}_{3} \mathrm{~N}, \mathrm{DMF}, \mathrm{rt}, 3$ days.

\section{Heterocyclic sugar analogues}

The synthesis of azatiazofurin 18 started from $\alpha$-L-lyxopyranoside 93. Activation of the free hydroxyl group with trimethylsilyl triflate, displacement with sodium azide and further catalytic hydrogenation resulted in aminosugar 94. Acid hydrolysis, followed by rearrangement and acetylation provided key intermediate 95, which was cyanylated to give nitrile 96. Treatment of this compound with hydrogen sulfide and ethylbromopyruvate followed by simultaneous deprotection and amide formation furnished 18 in 8 steps and 2\% overall yield from 93 (Scheme 19). [61] 
<smiles>CO[C@H]1OC[C@@H](O)[C@H]2OC(C)(C)O[C@H]12</smiles>

93<smiles>CC(=O)OC[C@@H]1[C@H](OC(C)=O)[C@H](OC(C)=O)[C@H](C#N)N1C(=O)C(F)(F)F</smiles>

96

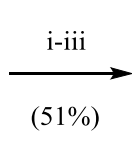<smiles>CO[C@H]1OC[C@@H](N)[C@H]2OC(C)(C)O[C@H]12</smiles>

94

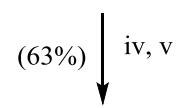

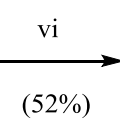<smiles>CC(=O)OC[C@H]1[C@H](OC(C)=O)[C@H](OC(C)=O)N1C(=O)OC(C)(F)F</smiles>

95<smiles>NC(=O)c1csc([C@@H]2N[C@H](CO)[C@@H](O)[C@H]2O)n1</smiles>

18

Scheme 19. Reagents and conditions: (i) $\mathrm{Tf}_{2} \mathrm{O}$, DMAP, pyridine, $\mathrm{CH}_{2} \mathrm{Cl}_{2}$. (ii) $\mathrm{NaN}_{3}, \mathrm{DMF}, \mathrm{rt}, 3 \mathrm{~h}$. (iii) $\mathrm{H}_{2}$, PD-C, EtOH, 50 psi, 16 h. (iv) $\mathrm{AcOH}, \mathrm{H}_{2} \mathrm{O}, 68^{\circ} \mathrm{C}, 2.5 \mathrm{~h}$, then $\mathrm{Ac}_{2} \mathrm{O}, \mathrm{AcOH}, \mathrm{H}_{2} \mathrm{SO}_{4}, 4^{\circ} \mathrm{C}, 2$ days. (v) TMSCN, $\mathrm{BF}_{3} \cdot \mathrm{Et}_{2} \mathrm{O}, 40^{\circ} \mathrm{C}$, 1h. (vi) $\mathrm{H}_{2} \mathrm{~S}, \mathrm{DMAP}, \mathrm{rt}, 2$ days then $\mathrm{BrCH}_{2} \mathrm{COCO}_{2} \mathrm{Et}, \mathrm{MeCN}^{\circ} 0^{\circ} \mathrm{C}, 1 \mathrm{~h}$, then rt, overnight. (vii) $\mathrm{NH}_{3}, \mathrm{MeOH}, 0^{\circ} \mathrm{C}, 5$ days.

Novel aza analogues of tiazofurin have been prepared for their evaluation as antiviral agents (Scheme 20). [62] The synthesis of intermediate nitrile 99 was carried out from $\gamma$-nitroaldehyde 97 which was prepared in multigram scale. Cyclization of $\mathbf{9 7}$ afforded pyrrolidine 98 which was transformed into 99 by treatment with $N$-chlrosuccinimide to generate an intermediate cyclic imine that was immediately cyanylated with hydrogen cyanide in the presence of Hünig's base. The cyanation step took place with 98\% chemical yield. In the case of using trimethylsilyl cyanide in the presence of cesium fluoride the yield dropped to $65 \%$. The construction of the thiazole ring was made through condensation of nitrile 99 with L-cysteine ethyl ester and subsequent oxidation with manganese (IV) oxide. Three different analogues 102a-c were prepared by treating 100 with ethanolic ammonia, hydroxylamine and hydrazine monohydrate followed by acidic hydrolysis with hydrochloric acid in methanol. 
<smiles>O=CCCC1([N+](=O)[O-])COC2(CCCC2)OC1</smiles>

97

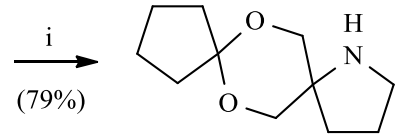

98

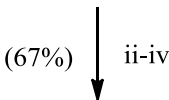<smiles>CCOC(=O)c1csc(C2CCC3(COC4(CCCC4)OC3)N2)n1</smiles>

99<smiles>[R]C(=N)NN(N)N=N</smiles>

Scheme 20. Reagents and conditions: (i) $\mathrm{Al}-\mathrm{HgCl}_{2}, \mathrm{THF}-\mathrm{H}_{2} \mathrm{O}, \mathrm{rt}, 3$ hours. (ii) NCS, THF, rt, 2 hours; (iii) DBU, $\mathrm{CH}_{2} \mathrm{Cl}_{2}$, rt, 3 hours. (iv) $2 \mathrm{M} \mathrm{HCN}$ in DIPE, rt, 24 hours. (v) $\left(\mathrm{CF}_{3} \mathrm{CO}\right){ }_{2} \mathrm{O}, \mathrm{Py}, \mathrm{DMAP}, 0 \circ \mathrm{C}, 2$ hours. (vi) L-cysteine ethyl ester $\cdot \mathrm{HCl}$, TEA, $\mathrm{MeOH}$, rt, 1.5 hours. (vii) $\mathrm{DBU}, \mathrm{BrCl}_{3}, \mathrm{CH}_{2} \mathrm{Cl}_{2}, 0 \circ \mathrm{C}, 24$ hours. (viii) for 101a: aq $\mathrm{NH}_{3}, \mathrm{EtOH}$, rt, 72 hours; for 101b: $\mathrm{NH}_{2} \mathrm{OH} \cdot \mathrm{HCl}$, EtONa, EtOH, rt, 24 hours; for 101c: $\mathrm{NH}_{2} \mathrm{NH}_{2} \cdot \mathrm{H}_{2} \mathrm{O}, \mathrm{EtOH}, \mathrm{rt}, 24$ hours. (ix) conc. $\mathrm{HCl}, \mathrm{MeOH} / \mathrm{H}_{2} \mathrm{O}, \mathrm{rt}, 1-3$ days.

Thiotiazofurin 19 was prepared from 1,2-di- $O$-acetyl-4-thioribofuranose 103. After obtention of the anomeric bromide 106 through conventional carbohydrate chemistry, nitrile 107 was obtained by treatment of $\mathbf{1 0 6}$ with mercury (ii) cyanide. The thiazole ring was formed by condensation with L-cysteine ethyl ester and oxidation with bromotrichloromethane in DBU. Deprotection and amide formation afforded 19 in 8 steps and $40.5 \%$ overall yield from 103 (Scheme 21). [63] 


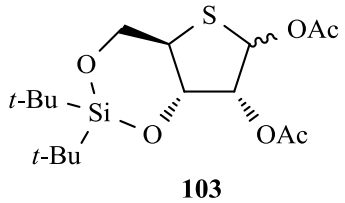

103

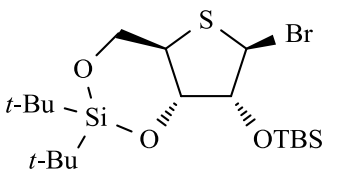

106

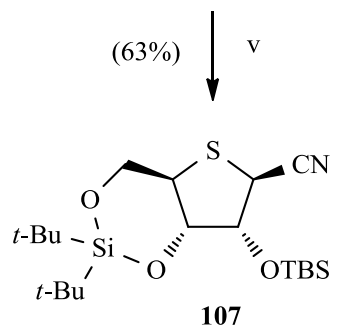

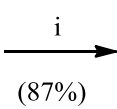

$t-\mathrm{Bu}-\mathrm{Si}-\mathrm{O}=\mathrm{OAc}$
$t-\mathrm{Bu}$

104
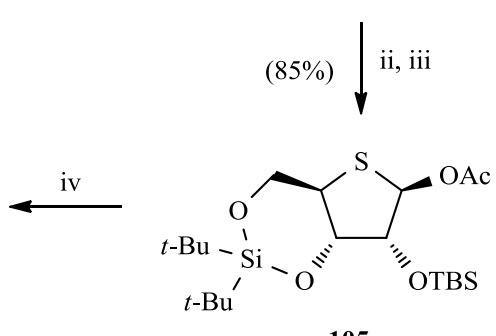

105

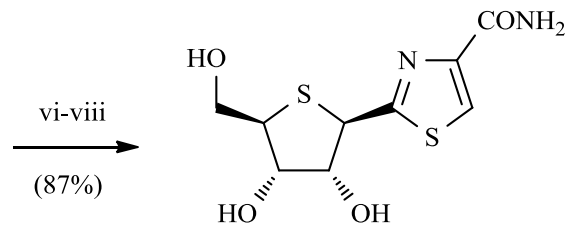

19

Scheme 21. Reagents and conditions: (i) (phenylthio)trimethylsilane, $\mathrm{SnCl}_{4} \mathrm{CH}_{2} \mathrm{Cl}_{2},-10^{\circ} \mathrm{C}, 10 \mathrm{~h}$. (ii) $\mathrm{MeOH}, \mathrm{NH}_{3}$, rt, overnight, then TBSCl, DMF, imidazole, rt, overnight. (iii) $\mathrm{Hg}(\mathrm{OAc})_{2}, \mathrm{AcOH}$, rt, $14 \mathrm{~h}$. (iv) TMSBr, $\mathrm{CH}_{2} \mathrm{Cl}_{2}$, rt, 27 h. (v) $\mathrm{Hg}(\mathrm{CN})_{2}, \mathrm{MeCN}$, rt, $22 \mathrm{~h}$. (vi) L-cysteine ethyl ester $\cdot \mathrm{HCl}, i-\mathrm{PrEt}_{2} \mathrm{~N}$, 1,2-dichloroethane, rt, 5 days. (vii) $\mathrm{DBU}, \mathrm{CBrCl}_{3}, \mathrm{CH}_{2} \mathrm{Cl}_{2}$, rt, 6 h. (viii) $\mathrm{NH}_{3}, \mathrm{MeOH}, \mathrm{rt}, 9 \mathrm{~h}$.

Optically active dioxolanyl analogue 112 was synthesized through condensation of thiazole 100 with chiral diol 111 in an acidic medium (Scheme 22). [64] Compound 110 was prepared in a one-pot procedure from 2,2-diethoxyacetamide 108 via reaction with $\mathrm{P}_{4} \mathrm{~S}_{10}$ and condensation with ethyl bromopyruvate.<smiles>CCOC(OCC)C(N)=O</smiles>

108<smiles>CCOC(OCC)C(N)=S</smiles>

109

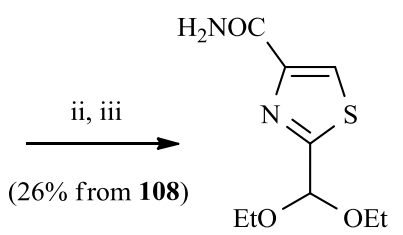

110<smiles>NC(=O)c1csc([C@H]2OC[C@@H](CO)O2)n1</smiles><smiles>CCCO[SbH2]C[C@H](O)CO</smiles>

112

Scheme 22. Reagents and conditions: (i) $\mathrm{P}_{4} \mathrm{~S}_{10}$, dioxane, r.t., 30 min. (ii) ethyl bromopyruvate, EtOH, reflux, 5h. (iii) $\mathrm{NH}_{3}, \mathrm{MeOH}$, r.t., 1 h. (iv) benzene, TsOH, reflux, 3h. (v) n-Bu ${ }_{4} \mathrm{NF}$, THF, r.t., lh.

Racemic 112 was also prepared by forming first the dioxolane ring and then constructing the thiazole ring by the same methodology, i.e. condensation of a thioamide with ethyl bromomopyruvate (Scheme 
23). [65] Compound 116 was preferentially obtained as the undesired trans-isomer. After formation of the thiazole ring, deprotection and amidation, the cis-dioxolane $\mathbf{1 1 2}$ was isolated in only 5\% overall yield.<smiles>CCOCC(COCC)OCC</smiles>

113<smiles>CCOC(=O)C(O)CO</smiles>

114<smiles>NC(=O)[C@@H]1OCC(C[18OH])O1</smiles>

115<smiles>NC(=O)c1csc([C@H]2OC[C@@H](CO)O2)n1</smiles>

$( \pm)-112$

Scheme 23. Reagents and conditions: (i) benzene, $\mathrm{TsOH}$, reflux. (ii) $\mathrm{NH}_{3}, \mathrm{MeOH}$, r.t. (iii) $\mathrm{H}_{2}$, PD-C, EtOH. (iv) $\mathrm{Ac}_{2} \mathrm{O}$, Py, rt. (v) $\mathrm{P}_{4} \mathrm{~S}_{10}$, dioxane, r.t. (vi) bromopyruvate, EtOH, reflux.

Dioxolanyl analogues bearing a triazole unit have been prepared by Chu and co-workers. [66] Starting from protected D-glyceraldehyde 117 the triazole ring was synthesized via the corresponding hydrazine derivative $\mathbf{1 1 8}$ obtained from the reaction of an intermediate anhydride with amidrazonate. Construction of the 1,3-dioxolane ring was carried out by condensation the free diol 119 with 2benzoyloxyacetaldehyde dimethyl acetal (Scheme 24). Two isomers were formed in this reaction and after chromatographic separation the desired cis isomer $\mathbf{1 2 0}$ was obtained in $51 \%$ yield from the diol after treatment with methanolic ammonia. The overall yield from D-glyceraldehyde was $17.9 \%$ / for 9 steps. Enantiomeric ent-118 was also prepared from L-glyceraldehyde ent-117 in 10.8\% overall yield (9 steps ). 
<smiles>CC1(C)OC[C@@H](C=O)O1</smiles>

117<smiles>CCOC(=O)/C(N)=N/NC(=O)[C@@H]1COC(C)(C)O1</smiles>

118

$(49 \%) \downarrow$ iv-vi<smiles>NC(=O)c1n[nH]c([C@H]2CO[C@@H](CO)O2)n1</smiles>

120<smiles>CC1(C)OC[C@H](C=O)O1</smiles>

ent-117<smiles>CCOC(=O)c1nc([C@@H](O)CO)n(Cc2ccccc2)n1</smiles>

119<smiles>NC(=O)c1n[nH]c([C@@H]2CO[C@@H](CO)O2)n1</smiles>

Scheme 24. Reagents and conditions: (i) $\mathrm{KMnO}_{4}, \mathrm{KOH}$, then $0.5 \mathrm{~N} \mathrm{H}_{2} \mathrm{SO}_{4}$. (ii) $\mathrm{ClCOOEt}, \mathrm{Et}_{3} \mathrm{~N}$, then $\mathrm{NH}_{4} \mathrm{OH}$. (iii) amidrazonate, $\left[\mathrm{H}_{2} \mathrm{~N}-\mathrm{N}=\mathrm{C}\left(\mathrm{NH}_{2}\right)-\mathrm{CO}_{2} \mathrm{Et}\right]$. (iv) reflux in xylene, 4 h. (v) $\mathrm{BnBr}, \mathrm{NaH}, \mathrm{DMF}$. (vi) $\mathrm{CF}_{3} \mathrm{CO}_{2} \mathrm{H}, \mathrm{THF} / \mathrm{H}_{2} \mathrm{O}(2: 1), 50{ }^{\circ} \mathrm{C}, 8 \mathrm{~h}$. (vii) $\mathrm{BzOCH}_{2} \mathrm{CH}(\mathrm{OMe})_{2}$, p-TsOH, benzene, reflux. (viii) $\mathrm{H}_{2}$, $\mathrm{PdCl}_{2}$, EtOH, 50 psi, 6 h. (ix) $\mathrm{NH}_{3}, \mathrm{MeOH}$, autoclave, $110^{\circ} \mathrm{C}, 24 \mathrm{~h}$.

Following a similar strategy to that illustrated in Scheme 23 for the synthesis of dioxo1any1 analogue 112, You and co-workers reported [67] the synthesis of a ring-expanded 1,3-dioxane analogue (Scheme 25). Condensation of $\mathbf{1 1 3}$ with diols 121 afforded 1,3-dioxanes 122. These compounds were transformed into 123 which were used for constructing the thiazole ring and obtaining, after deprotection and amide formation, the analogues 124.<smiles>CCOC(COc1ccccc1)OCC</smiles>

113

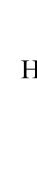<smiles>[R]C(CO)(CO)C(=O)O</smiles>

121a $\mathrm{R}=\mathrm{Me}$

121b $\mathrm{R}=\mathrm{Et}$<smiles>[R]C1(c2nc(C(N)=O)cs2)COC(COC(C)C)OC1</smiles>

124a $\mathrm{R}=\mathrm{Me} \quad(6.5 \%)$

124b $\mathrm{R}=\mathrm{Et} \quad(7.3 \%)$

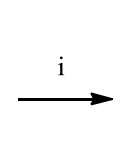<smiles>[R]C1(C(=O)O)COC(COCc2ccccc2)OC1</smiles>

122a $\mathrm{R}=\mathrm{Me}(83 \%)$

122b $\mathrm{R}=\mathrm{Et} \quad(85 \%)$
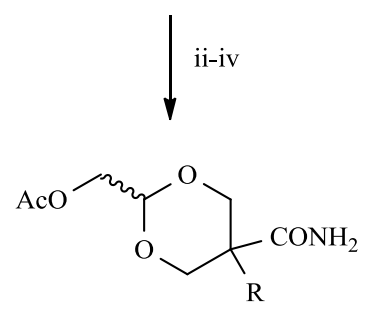

123a $\mathrm{R}=\mathrm{Me} \quad(63 \%)$

123b $\mathrm{R}=\mathrm{Et} \quad(50 \%)$ 
Scheme 25. Reagents and conditions: (i) THF, $\mathrm{BF}_{3} \cdot \mathrm{Et}_{2} \mathrm{O}, 24 \mathrm{~h}$. (ii) $\mathrm{ClCOOEt}, \mathrm{THF}, \mathrm{TEA},-20^{\circ} \mathrm{C}$ to rt., 30 min, then $\mathrm{NH}_{3}$ (g), $-20^{\circ} \mathrm{C}$ to rt., 20 h. (iii) PD-C, $\mathrm{H}_{2}, \mathrm{MeOH}, 10$ h. (iv) $\mathrm{Ac}_{2} \mathrm{O}$, Py, rt., 12 h. (v) $\mathrm{P}_{4} \mathrm{~S}_{10}$, dioxane, reflux, 1 h. (vi) $\mathrm{BrCH}_{2} \mathrm{COCO}_{2} \mathrm{Et}$, EtOH, reflux, 2 h. (vii) $\mathrm{NH}_{3}, \mathrm{MeOH}$, rt., 3 days.

Several isoxazolidinyl analogues of tiazofurin have been prepared through diverse strategies based on 1,3-dipolar chemistry of nitrones. The cycloaddition of D-glyceraldehyde-derived nitrone 125 with acrylonitrile afforded a 35:50:10:5 mixture of adducts from which the major one $\mathbf{1 2 6}$ was chromatographically separated (Scheme 26). [68] Formation of the thiazole ring was achieved by condensation with L-cysteine ethyl ester and oxidation with manganese (IV) oxide. The hydroxymethyl group was unmasked by acetonide hydrolysis and further oxidation to obtain an intermediate aldehyde which was subsequently reduced with sodium borohydride. Final formation of the amide moiety furnished the analogue $\mathbf{1 2 8}$ in $23.3 \%$ overall yield from nitrone $\mathbf{1 2 5}$ (7 steps).<smiles>CC1(C)OCC(C=[N+]([O-])Cc2ccccc2)O1</smiles>

125<smiles>NC(=O)c1csc([C@@H]2C[C@H](CO)N(Cc3ccccc3)O2)n1</smiles>

128<smiles>CC1(C)OC[C@@H](C2C[C@H](C#N)ON2Cc2ccccc2)O1</smiles>

$\mathrm{Bn}^{\prime}$<smiles>CCOC(=O)c1csc([C@H]2C[C@H]([C@H]3COC(C)(C)O3)N(Cc3ccccc3)[C@H]2C)n1</smiles>

Scheme 26. Reagents and conditions: (i) acrylonitrile, reflux, 4 h. (ii) L-cysteine ethyl ester $\cdot$ HCl, TEA, $\mathrm{MeOH}, \mathrm{rt}, 3$ hours. (iii) $\mathrm{MnO}_{2}$, benzene, reflux, 12 h. (iv) EtOH, pTsOH, $60^{\circ} \mathrm{C}, 4$ h. (v) $\mathrm{CH}_{2} \mathrm{Cl}_{2}$, aq $\mathrm{NaIO} 4$, rt, 15 min. (vi) $\mathrm{NaBH}_{4}, \mathrm{MeOH}, 0^{\circ} \mathrm{C}, 1$ h. (vii) $\mathrm{NH}_{3}, \mathrm{MeOH}, \mathrm{rt}, 1$ h.

An enantiomeric unsubstituted derivative of $\mathbf{1 2 8}$ was prepared by the same authors [68] using nitrone 131 generated in situ. The opposite asymmetric induction exerted by chiral hydroxylamine 127 furnished intermediate 132 which was transformed into 133 following the same sequence of reactions illustrated in Scheme 26 and finishing with an acidic treatment to eliminate the chiral auxiliary. Thus, the analogue 133 was obtained in 8 steps and 36\% overall yield from aldehyde 129 (Scheme 27). 


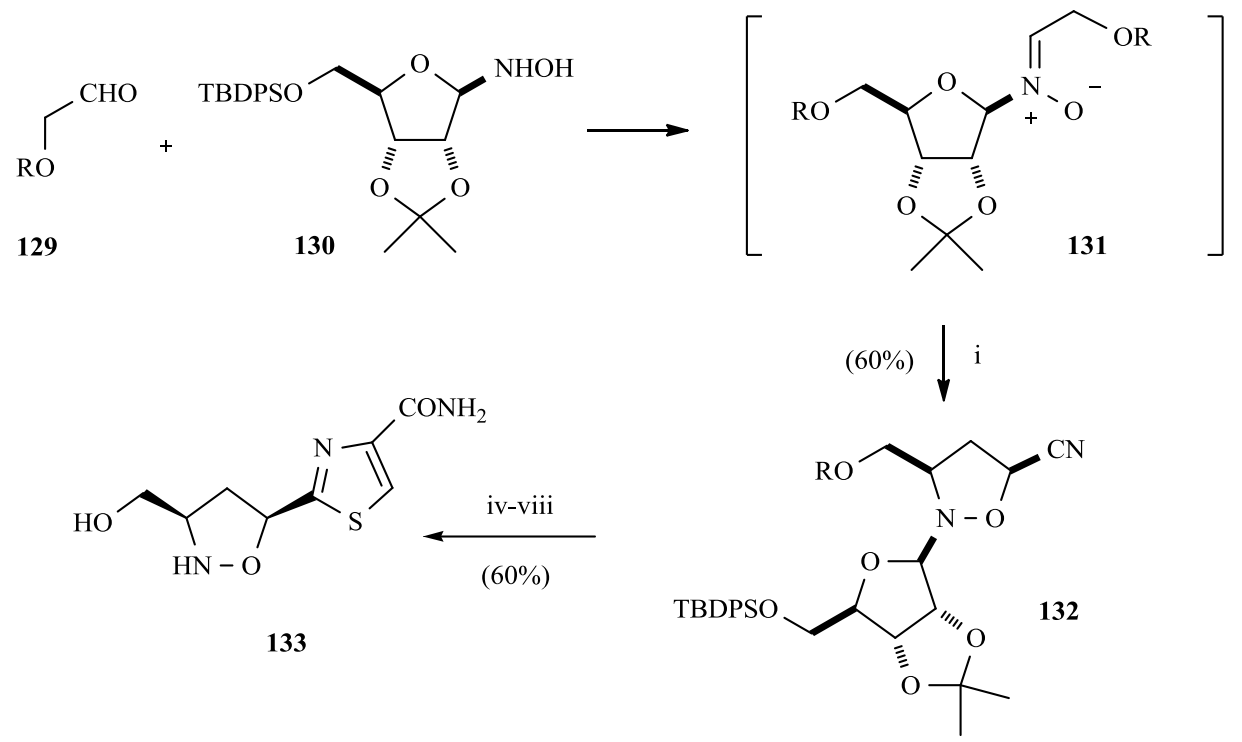

Scheme 27. Reagents and conditions: (i) acrylonitrile, reflux, 4 h. (ii) L-cysteine ethyl ester · HCl, TEA, $\mathrm{MeOH}$, rt, 3 hours. (iii) $\mathrm{MnO}_{2}$, benzene, reflux, 12 h. (iv) EtOH, pTsOH, $60^{\circ} \mathrm{C}$, 4h. (v) $\mathrm{CH}_{2} \mathrm{Cl}_{2}$, aq $\mathrm{NaIO}_{4}$, rt, 15 min. (vi) $\mathrm{NaBH}_{4}, \mathrm{MeOH}, 0^{\circ} \mathrm{C}, 1$ h. (vii) $\mathrm{NH}_{3}, \mathrm{MeOH}, \mathrm{rt}, 1$ h. (viii) $1.5 \% \mathrm{HCl}$ in EtOH, rt, 3 h.

Compounds 128 and 133 presented the thiazole ring in a vicinal position to the oxygen atom of the isoxazolidine ring. The corresponding regioisomeric analogue in which the thiazole ring was placed vicinal to the nitrogen atom of the isoxazolidine ring was also synthesized. [69]

Racemic $\mathbf{1 3 5}$ was directly prepared from nitrone $\mathbf{1 3 4}$ synthesized by the Hantzsch's method from thioamide $\mathbf{1 0 9}$ and ethyl bromopyruvate. Cycloaddition of $\mathbf{1 3 4}$ with allylic alcohol under a variety of conditions furnished mixtures of cis and trans adducts. However, when the reaction was carried out in the presence of 1.0 eq of zinc (11) triflate and under microwave irradiation, only the desired cis isomer $\mathbf{1 3 5}$ was obtained (Scheme 28)<smiles>CC(C)(C)COC(=O)OC(O)C(N)=S</smiles>

109<smiles>NC(=O)c1csc([C@@H]2C[C@H](CO)ON2)n1</smiles>

$( \pm)-135$<smiles>CCOC(OCC)c1csc(C(OCC)OCC)n1</smiles>

110<smiles>CC(C)[NH2+]/C([NH2+])=C/c1nc(C(N)=O)cs1</smiles>

134

Scheme 28. Reagents and conditions: (i) ethyl bromopyruvate, EtOH, molecular sieves, reflux, 90 min. (ii) $\mathrm{NH}_{3}, \mathrm{MeOH}$, r.t., 24 h. (iii) $1 \mathrm{M} \mathrm{HCl}$, reflux, 1 h. (iv) $\mathrm{MgSO}_{4}, \mathrm{CH}_{2} \mathrm{Cl}_{2}, \mathrm{BnNHOH}$, rt, 6h. (v) allylic alcohol, $\mathrm{CH}_{2} \mathrm{Cl}_{2}, \mathrm{Zn}(\mathrm{OTf})_{2}$, MW 90 watt, $160^{\circ} \mathrm{C}, 15 \mathrm{~min}$. 
In order to introduce chirality in the process to obtain optically active derivatives, chiral hydroxylamines such as $\mathbf{1 3 0}$ was used to prepare the corresponding nitrones. However, any attempt of conducting the reaction in the presence of Lewis acids only afforded complex reaction mixtures of various compounds from which it was not possible to separate any adduct in a synthetically useful way.

On the other hand, the cycloaddition of nitrone 136, obtained as illustrated in Scheme 28, with chiral nonracemic monoprotected diol $\mathbf{1 3 7}$ afforded a 4:1 mixture of isomers from which compound $\mathbf{1 3 8}$ was separated. After deprotection, diol cleavage and amide formation, compound $\mathbf{1 2 8}$ was obtained in 5 steps and 53\% overall yield from nitrone $\mathbf{1 3 6}$ (Scheme 29).<smiles>C=C[C@H](O)CO[Hg]CCC</smiles><smiles>NC(=O)c1csc([C@@H]2CC(CO)O[N]2)n1</smiles>

128<smiles>COC[C@H](O)C1CC(c2nc(C(=O)OC)cs2)[N]O1</smiles>

138

Scheme 29. Reagents and conditions: (i) $\mathrm{CH}_{2} \mathrm{Cl}_{2}, \mathrm{Zn}(\mathrm{OTf})_{2}$, $\mathrm{MW} 90$ watt, $120^{\circ} \mathrm{C}, 2$ min. (ii) $\mathrm{Bu}_{4} \mathrm{NF}$, THF, rt, 3 h. (iii) $\mathrm{CH}_{2} \mathrm{Cl}_{2}$, aq $\mathrm{NaIO}_{4}$, rt, 15 min. (iv) $\mathrm{NaBH}_{4}, \mathrm{MeOH}, 0^{\circ} \mathrm{C}, 1$ h.. (v) $\mathrm{NH}_{3}$, $\mathrm{MeOH}$, r.t., 24 h.

The synthesis of thiophenthiofurin $\mathbf{2 0}$ and furanthiofurin $\mathbf{2 1}$ have been reported by Franchetti and coworkers. [70] Compound $\mathbf{2 0}$ was prepared by direct glycosylation of tetraacetyl derivative $\mathbf{1 3 9}$ with ethyl thiophene-3-carboxylate (140). The reaction gave a mixture of 2- and 5-glycosylated regioisomers as $\alpha$ and $\beta$ anomers in $56 \%$ yield. The mixture was treated with methanolic ammonia and the target 20 was separated by column chromatography (Scheme 30). Similarly, glycosylation of tribenzylated 141 with furan derivative $\mathbf{1 4 2}$ gave, after deprotection and amide formation, furanthiofurin $\mathbf{2 1}$.<smiles>CC(=O)OC[C@H]1S[C@@H](OC(C)=O)[C@H](OC(C)=O)[C@@H]1OC(C)=O</smiles>

139<smiles>CC(=O)O[C@H]1S[C@H](CO)[C@@H](O[C@H](Cc2ccccc2)c2ccccc2)[C@@H]1OCc1ccccc1</smiles>
141

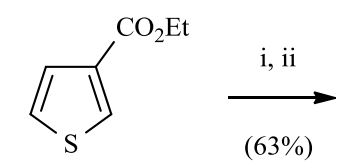

140

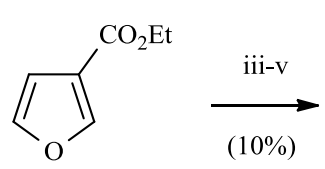

142<smiles>NC(=O)c1csc([C@@H]2S[C@H](CO)[C@@H](O)[C@H]2O)c1</smiles>

20<smiles>NC(=O)c1coc([C@@H]2S[C@H](CO)[C@@H](O)[C@H]2O)c1</smiles>

21 
Scheme 30. Reagents and conditions: (i) $\mathrm{SnCl}_{4}, 1,2$-dichloroethane, $0^{\circ} \mathrm{C}, 30 \mathrm{~min}, \mathrm{rt}, 24 \mathrm{~h}$. (ii) $\mathrm{NH}_{3}$, $\mathrm{MeOH}$, then $\mathrm{NH}_{4} \mathrm{OH}$, rt, 24 h. (iii) TFA, $\mathrm{CH}_{2} \mathrm{Cl}_{2}, 0^{\circ} \mathrm{C}, 15$ min, then warm to rt. (iv) $\mathrm{BBr}_{3}, \mathrm{CH}_{2} \mathrm{Cl}_{2},-78^{\circ} \mathrm{C}$, 1h. (v) $30 \% \mathrm{NH}_{4} \mathrm{OH}, \mathrm{rt}, 24 \mathrm{~h}$.

\section{Acknowledgements}

This study was supported by the Ministerio de Ciencia e lnnovacion (MICINN) and FEDER Program (Madrid, Spain, project CTQ2010-19606) and the Gobierno de Aragon (Zaragoza, Spain, Bioorganic Chemistry Group. E-10). M.G. thanks MEC for a FPU predoctoral grant.

\section{References}

[1] Jackson, R.; Weber, G.; Morris, H. P. IMP dehydrogenase, an enzyme linked with proliferation and malignancy. Nature 1975, 256, 331-333.

[2] Hedstrom, L. IMP Dehydrogenase: Structure, Mechanism, and Inhibition. Chem. Rev. 2009, 109, 2903-2928.

[3] (a) Shu, Q.; Nair, V. Inosine monophosphate dehydrogenase (IMPDH) as a target in drug discovery. Med. Res. Rev. 2008, 28, 219-232. (b) Braun-Sand, S. B.; Peetz, M. Inosine monophosphate dehydrogenase as a target for antiviral, anticancer, antimicrobial and immunosuppressive therapeutics. Future Med. Chem. 2010, 2, 81-92.

[4] (a) Chen, L.; Pankiewicz, K. W. Recent development of IMP dehydrogenase inhibitors for the treatment of cancer. Curr. Op. Drug Discov. Dev. 2007, 10, 403-412. (b) Oláh, E.; Kökény, S.; Papp, J.; Bozsik, A.; Keszei, M. Modulation of cancer pathways by inhibitors of guanylate metabolism. Adv. Enzyme Regul. 2006, 46, 176-190. (c) Weber, G. IMPDH, and GTP: linkage with neoplasia, target of chemotherapy, regulation of Ras, signal transduction, and apoptosis. ACS Symp. Series 2003, 839, 20-47.

[5] (a) Nair, V.; Shu, Q. Inosine monophosphate dehydrogenase as a probe in antiviral drug discovery. Antiviral Chem. Chemother. 2007, 18, 245-258. (b) Khan, M.; Dhanwani, R.; Patro, I. K.; Rao, P. V. L.; Parida, M. M. Cellular IMPDH enzyme activity is a potential target for the inhibition of Chikungunya virus replication and virus induced apoptosis in cultured mammalian cells. Antiviral Res. 2011, 89, 1-8. (c) Gong, J.; Fang, H.; Li, M.; Liu, Y.; Yang, K.; Liu, Y.; Xu, W. Potential targets and their relevant inhibitors in anti-influenza fields. Curr. Med. Chem. 2009, 16, 37163739.

[6] Ratcliffe, A. J. Inosine 5'-monophosphate dehydrogenase inhibitors for the treatment of autoimmune diseases. Curr. Op. Drug Discov. Dev. 2006, 9, 595-605.

[7] Hedstrom, L.; Liechti, G.; Goldberg, J. B.; Gollapalli, D. R. The antibiotic potential of prokaryotic IMP dehydrogenase inhibitors. Curr. Med. Chem. 2011, 18, 1909-1918.

[8] (a) Franchetti, P.; Grifantini, M. Nucleoside and non-nucleoside IMP dehydrogenase inhibitors as antitumor and antiviral agents. Curr. Med. Chem. 1999, 6, 599-614. (b) Pankiewicz, K. W. Inhibitors of inosine monophosphate dehydrogenase as potential chemotherapeutic agents. Expert Op. Ther. Pat. 2001, 11, 1161-1170. 
[9] (a) Goldstein, B. M.; Colby, T. D. IMP dehydrogenase: structural aspects of inhibitor binding. Curr. Med. Chem. 1999, 6, 519-536. (b) Hedstrom, L. IMP dehydrogenase: mechanism of action and inhibition. Curr. Med. Chem. 1999, 6, 545-560.

[10] Bentley, R. Mycophenolic Acid: A One Hundred Year Odyssey from Antibiotic to Immunosuppressant. Chem. Rev. 2000, 100, 3801-3825.

[11] Makara, G. M.; Keseru, G. M.; Kajtar-Peredy, M.; Anderson, W. K. Nuclear Magnetic Resonance and Molecular Modeling Study on Mycophenolic Acid: Implications for Binding to Inosine Monophosphate Dehydrogenase. J. Med. Chem. 1996, 39, 1236-1242.

[12] (a) Reyes, G. R. Ribavirin: recent insights into antiviral mechanisms of action. Curr. Op. Drug Discov. Dev.2001, 4, 651-656. (b) Mori, K.; Ikeda, M.; Ariumi, Y.; Dansako, H.; Wakita, T.; Kato, N. Mechanism of action of ribavirin in a novel hepatitis $\mathrm{C}$ virus replication cell system. Virus Res. 2011, 157, 61-70.

[13] Prosise, G. L.; Wu, J. Z.; Luecke, H. Crystal Structure of Tritrichomonas foetus Inosine Monophosphate Dehydrogenase in Complex with the Inhibitor Ribavirin Monophosphate Reveals a Catalysis-dependent Ion-binding Site. J. Biol. Chem.2002, 277, 50654-50659.

[14] Gharehbaghi, K.; Grunberger, W.; Jayaram, H. N. Studies on the mechanism of action of benzamide riboside: a novel inhibitor of IMP dehydrogenase. Curr. Med. Chem. 2002, 9, 743-748.

[15] Kerr, K. M.; Hedstrom, L. The Roles of Conserved Carboxylate Residues in IMP Dehydrogenase and Identification of a Transition State Analog. Biochemistry 1997, 36, 13365-13373.

[16] Digits, J. A.; Hedstrom, L. Drug selectivity is determined by coupling across the NAD+ site of IMP dehydrogenase. Biochemistry 2000, 39, 1771-1777.

[17] Pankiewicz, K. W.; Watanabe, K. A.; Lesiak-Watanabe, K.; Goldstein, B. M.; Jayaram, H. N. The chemistry of nicotinamide adenine dinucleotide (NAD) analogues containing C-nucleosides related to nicotinamide riboside. Curr. Med. Chem. 2002, 9, 733-741.

[18] Zhou, T.; Kurnasov, O.; Tomchick, D. R.; Binns, D. D.; Grishin, N. V.; Marquez, V. E.; Osterman, A. L.; Zhang, H. Structure of Human Nicotinamide/Nicotinic Acid Mononucleotide Adenylyltransferase. J. Biol. Chem.2002, 277, 13148-13154.

[19] Pankiewicz, K. W.; Goldstein, B. M. NAD analogues 18 - The chemistry of nucleoside and dinucleotide inhibitors of inosine monophosphate dehydrogenase (IMPDH). Recent Adv. Nucleos. 2002, 71-90.

[20] Petrelli, R.; Vita, P.; Torquati, I.; Felczak, K.; Wilson, D. J.; Franchetti, P.; Cappellacci, L. Novel inhibitors of inosine monophosphate dehydrogenase in patent literature of the last decade. Recent Pat. Anti-Cancer Drug Disc. 2013, 8, 103-125.

[21] Romeo, G.; Chiacchio, U.; Corsaro, A.; Merino, P. Chemical Synthesis of Heterocyclic-Sugar Nucleoside Analogues. Chem. Rev. 2010, 110, 3337-3370.

[22] Merino, P. Chemical Synthesis of Nucleoside Analogues; John Wiley \& sons: Hoboken, New Jersey, 2013. 912 pp.

[23] (a) Pankiewicz, K. W.; Patterson, S. E.; Black, P. L.; Jayaram, H. N.; Risal, D.; Goldstein, B. M.; Stuyver, L. J.; Schinazi, R. F. Cofactor mimics as selective inhibitors of NAD-dependent inosine monophosphate dehydrogenase (IMPDH) - the major therapeutic target. Curr. Med. Chem. 2004, 
11,887-900. (b) Pankiewicz, K. W. Inhibitors of inosine monophosphate dehydrogenase as potential chemotherapeutic agents. Expert Op. Ther. Pat. 1999, 9, 55-65.

[24] (a) Franchetti, P.; Cappellacci, L.; Grifantini, M.; Jayaram, H. N.; Goldstein, B. M. C-Nucleoside analogs of tiazofurin and selenazofurin as inosine 5'-monophosphate dehydrogenase inhibitors. ACS Symp. Ser. 2003, 839, 212-230. (b) Pankiewicz, K. W.; Patterson, S.; Jayaram, H. N.; Goldstein, B. M. Cofactor analogues as inhibitors of IMP dehydrogenase: Design and new synthetic approaches. ACS Symp. Ser. 2003, 839, 247-281, 1 plate.

[25] Srivastava, P. C.; Pickering, M. V.; Allen, L. B.; Streeter, D. G.; Campbell, M. T.; Witkowski, J. T.; Sidwell, R. W.; Robins, R. K. Synthesis and antiviral activity of certain thiazole C-nucleosides. J. Med. Chem. 1977, 20, 256-262.

[26] Ramasamy, K. S.; Bandaru, R.; Averett, D. A New Synthetic Methodology for Tiazofurin. J. Org. Chem. 2000, 65, 5849-5851.

[27] Hennen, W. J.; Hinshaw, B. C.; Riley, T. A.; Wood, S. G.; Robins, R. K. Synthesis of 4substituted 5-amino-2-( $\beta$-D-ribofuranosyl)thiazoles and 4-substituted 5-amino-2-( $\beta$-Dribofuranosyl)selenazoles, and their respective conversion into 2-( $\beta$-D-ribofuranosyl)thiazolo[5,4d]pyrimidines and 2-( $\beta$-D-ribofuranosyl)selenazolo[5,4-d]pyrimidines. A new synthesis of tiazofurin and selenazofurin. J. Org. Chem. 1985, 50, 1741-1746.

[28] Ramasamy, K. S.; Lau, J. Y. N. A new synthetic methodology for tiazofurin. Nucleosides, Nucleotides 2001, 20, 1329-1331.

[29] Brown, R. S.; Dowden, J.; Moreau, C.; Potter, B. V. L. A concise route to tiazofurin. Tetrahedron Lett. 2002, 43, 6561-6562.

[30] (a) Weber, G.; Shen, F.; Orban, T. I.; Kökény, S.; Oláh, E. Targeting signal transduction. Adv. Enzyme Regul. 2003, 43, 47-56. (b) Yalowitz, J. A.; Pankiewicz, K.; Patterson, S. E.; Jayaram, H. N. Cytotoxicity and cellular differentiation activity of methylenebis(phosphonate) analogs of tiazofurin and mycophenolic acid adenine dinucleotide in human cancer cell lines. Cancer Lett. (Shannon, Ireland) 2002, 181, 31-38. (c) Grifantini, M. Tiazofurine ICN Pharmaceuticals. Curr. Opin. Investig. Drugs 2000, 1, 257-262. (d) Vranic-Mandusic, V.; Subota, V.; Savovski, K.; Medic, L.; Dramicanin, T.; Jozanov-Stankov, O.; Popov-Celeketic, D.; Jokanovic, M.; Dimitrijevic, B. Erythrocytotoxicity of tiazofurin in vivo and in vitro detected by scanning probe microscopy. Toxicol. Lett. 2004, 146, 275-284. (e) Vranic, V.; Savovski, K.; Dedovic, N.; Dimitrijevic, B. Hematological toxicity associated with tiazofurin-influence on erythropoiesis. Toxicol. Lett. 2000, 114, 81-90.

[31] Popsavin, M.; Spaic, S.; Svircev, M.; Kojic, V.; Bogdanovic, G.; Popsavin, V. Synthesis and in vitro antitumor screening of 2-( $\beta$-D-xylofuranosyl)thiazole-4-carboxamide and two novel tiazofurin analogs with substituted tetrahydrofurodioxol moiety as a sugar mimic. Bioorg. Med. Chem. Lett. 2012, 22, 6700-6704.

[32] Mao, D. T.; Marquez, V. E. Synthesis of 2- $\beta$-D-ara- and 2- $\beta$-D-xylofuranosylthiazole-4carboxamide. Tetrahedron Lett. 1985, 25, 2111-2114.

[33] Goldstein, B. M.; Mao, D. T.; Marquez, V. E. Ara-tiazofurin: Conservation of Structural Features in an Unusual Thiazole Nucleoside. J. Med. Chem. 1988, 31, 1026-1031. 
[34] (a) Hanna, N. B.; Upadhya, K. G.; Petrie, C. R.; Robins, R. K.; Revankar, G. R. Synthesis of certain 5'-substituted derivatives of ribavirin and tiazofurin. Nucleosides, Nucleotides 1986, 5, 343362. (b) Andres, J. I.; Garcia-Lopez, M. T.; De las Heras, F. G.; Mendez-Castrillon, P. P. Synthesis of 2-( $\beta$-D-ribofuranosyl)thiazole-4-carboxamide 5'-phosphate isosters. Nucleosides, Nucleotides 1986, 5, 423-429.

[35] Baur, R. H.; Baker, D. C. Synthesis of 2-(3-deoxy- $\beta$-D-erythro-pentofuranosyl)thiazole-4carboxamide (3'-deoxytiazofurin). Nucleosides, Nucleotides 1984, 3, 77-89.

[36] Jayaram, H. N.; Dion, R. L.; Glazer, R. I.; Johns, D. G.; Robins, R. K.; Srivastava, P. C.; Cooney, D. A. Initial studies on the mechanism of action of a new oncolytic thiazole nucleoside, $2-\beta-D-$ ribofuranosylthiazole-4-carboxamide (NSC 286193). Biochem. Pharm. 1982, 31, 2371-2380.

[37] Popsavin, M.; Torovic, L.; Kojic, V.; Bogdanovic, G.; Spaic, S.; Popsavin, V. De novo synthesis of two new cytotoxic tiazofurin analogues with modified sugar moieties. Bioorg. Med. Chem. Lett. 2003, 13, 3167-3170.

[38] (a) Popsavin, M.; Popsavin, V.; Vukojević, N.; Csanádi, J.; Miljković, D. Preparation of 2,5anhydro-3,4,6-tri-O-benzoyl-D-allononitrile from D-glucose. Carbohydr. Res. 1994, 260, 145-150. (b) Popsavin, M.; Torović, L.; Spaić, S.; Stankov, S.; Kapor, A.; Tomić, Z.; Popsavin, V. Synthesis and biological evaluation of new pyrazole- and tetrazole-related C-nucleosides with modified sugar moieties. Tetrahedron 2002, 58, 569-580.

[39] Popsavin, M.; Torovic, L.; Kojic, V.; Bogdanovic, G.; Popsavin, V. Synthesis and biological evaluation of two novel 2'-substituted tiazofurin analogues. Tetrahedron Lett. 2004, 45, 71257128.

[40] Popsavin, M.; Torovic, L.; Svircev, M.; Kojic, V.; Bogdanovic, G.; Popsavin, V. Synthesis and antiproliferative activity of two new tiazofurin analogs with 2'-amido functionalities. Bioorg. Med. Chem. Lett. 2006, 16, 2773-2776.

[41] Popsavin, M.; Spaic, S.; Svircev, M.; Kojic, V.; Bogdanovic, G.; Popsavin, V. 2-(3-Amino-3deoxy- $\beta$-D-xylofuranosyl)thiazole-4-carboxamide: A new tiazofurin analog with potent antitumor activity. Bioorg. Med. Chem. Lett. 2006, 16, 5317-5320.

[42] Popsavin, M.; Spaic, S.; Svircev, M.; Kojic, V.; Bogdanovic, G.; Popsavin, V. Synthesis and antitumor activity of new tiazofurin analogs bearing a 2,3-anhydro functionality in the furanose ring. Bioorg. Med. Chem. Lett. 2007, 17, 4123-4127.

[43] Popsavin, M.; Spaic, S.; Svircev, M.; Kojic, V.; Bogdanovic, G.; Pejanovic, V.; Popsavin, V. Synthesis of highly cytotoxic tiazofurin mimics bearing a 2,3-anhydro function in the furanose ring. Tetrahedron 2009, 65, 7637-7645.

[44] Liang, C. W.; Kim, M. J.; Jeong, L. S.; Chun, M. W. Synthesis of 2-(3'-Azido- and 3'-Amino-3'deoxy- $\beta$-D-ribofuranosyl)thiazole-4-carboxamide. Nucleosides, Nucleotides 2003, 22, 2039-2048.

[45] Chun, M. W.; Kim, M. J.; Shin, J. H.; Jeong, L. S. Synthesis of 3'-deoxy-3'-C-hydroxymethyl analogs of tiazofurin and ribavirin. Nucleosides, Nucleotides 2005, 24, 975-977.

[46] Lin, T.-S.; Zhu, J.-L.; Dutschman, G. E.; Cheng, Y.-C.; Prusoff, W. H. Synthesis and biological evaluations of 3'-deoxy-3'-C-brancheD-chain-substituted nucleosides. J. Med. Chem. 1993, 36, 353-362. 
[47] Nair, V.; Wenzel, T. Synthesis and antiviral studies of a novel isodideoxynucleoside: an analogue of the antiviral compound, tiazofurin. ARKIVOC 2004, 128-132.

[48] Kovacs, L.; Herczegh, P.; Batta, G.; Farkas, I. Two acyclic analogs of 2- $\beta$-Dribofuranosylthiazole-4-carboxamide (tiazofurin). Heterocycles 1987, 26, 947-60.

[49] Kikuchi, Y.; Nishiyama, S.; Yamamura, S.; Kato, K.; Fujiwara, S.; Umczawa, K.; Terada, Y. Synthesis of C-oxetanosyl-thiazole and its carbocyclic analog nucleosides as potential chemotherapeutic agents. Bioorg. Med. Chem. Lett. 1996, 6, 1897-1900.

[50] Kovacs, L.; Herczegh, P.; Batta, G.; Farkas, I. Thiazole C-nucleosides. III. Synthesis of pyranose analogs of tiazofurin. Tetrahedron 1991, 47, 5539-48.

[51] Hennen, W. J.; Hinshaw, B. C.; Riley, T. A.; Wood, S. G.; Robins, R. K. Synthesis of 4Substituted 5-Amino-2-( $\beta$-D-ribofuranosyl)thiazoles and 4-Substituted 5-Amino-2-( $\beta$-Dribofuranosyl)selenazoles andTheir Respective Conversion into 2-( $\beta$-DRibofuranosyl)thiazolo[5,4-d]pyrimidines and 2-( $\beta$-D-Ribofuranosyl)selenazolo[5,4d]pyrimidines. A New Synthesis of Tiazofurin and Selenazofurin. J. Org. Chem., 50, 1741-1746.

[52] Franchetti, P.; Cristalli, G.; Grifantini, M.; Cappellacci, L.; Vittori, S.; Nocentini, G. Synthesis and Antitumor Activity of 2-b-D-Ribofuranosyloxazole-4-carboxamide (Oxazofurin). J. Med. Chem. 1990, 33, 2849-2852.

[53] Franchetti, P.; Messini, L.; Cappellacci, L.; Grifantini, M.; Guarracino, P.; Marongiu, M. E.; Piras, G.; La Colla, P. A new facile synthesis and antiviral activity of oxazofurin. Nucleosides, Nucleotides 1993, 12, 359-368.

[54] Franchetti, P.; Marchetti, S.; Cappellacci, L.; Yalowitz, J. A.; Jayaram, H. N.; Goldstein, B. M.; Grifantini, M. A new C-nucleoside analog of tiazofurin synthesis and biological evaluation of 2- $\beta$ D-ribofuranosylimidazole-4-carboxamide (imidazofurin). Bioorg. Med. Chem. Lett. 2001, 11, 6769.

[55] Maeba, I.; Ito, Y.; Wakimura, M.; Ito, C. C-Nucleosides. 21. Synthesis of Isoxazole C-Nucleoside from Furanone Glycoside via Enaminone Glycoside. Heterocycles 1993, 36, 1617-1623.

[56] Nishimura, N.; Banno, M.; Maki, A.; Nishiyama, Y.; Maeba, I. Synthesis of 3- $\beta$-Dribofuranosylpyrazole-1-carboxamide. Carbohydr.Res. 1998, 307, 211-215.

[57] (a) Cappellacci, L.; Franchetti, P.; Grifantini, M.; Messini, L.; Sheikha, G. A.; Nocentini, G.; Moraca, R.; Goldstein, B. M. Synthesis, antitumor activity and crystallographic studies of analogs of tiazofurin. Nucleosides, Nucleotides1995, 14, 637-640. (b) Cappellacci, L.; Franchetti, P.; Sheikha, G. A.; Jayaram, H. N.; Gurudutt, V. V.; Sint, T.; Schneider, B. P.; Goldstein, B. M.; Perra, G.; Colla, P. L.; Grifantini, M. Synthesis and cytotoxic activity of selenophenfurin, a new inhibitor of IMP dehydrogenase. Nucleosides, Nucleotides 1997, 16, 1045-1048.

[58] (a) Franchetti, P.; Cappellacci, L.; Abu Sheikha, G.; Jayaram, H. N.; Gurudutt, V. V.; Sint, T.; Schneider, B. P.; Jones, W. D.; Goldstein, B. M.; Perra, G.; De Montis, A.; Loi, A. G.; La Colla, P.; Grifantini, M. Synthesis, Structure, and Antiproliferative Activity of Selenophenfurin, an Inosine 5'-Monophosphate Dehydrogenase Inhibitor Analog of Selenazofurin. J. Med. Chem. 1997, 40, 1731-1737. (b) Franchetti, P.; Cappellacci, L.; Grifantini, M.; Barzi, A.; Nocentini, G.; Yang, H.; O'Connor, A.; Jayaram, H. N.; Carrell, C.; Goldstein, B. M. Furanfurin and 
Thiophenfurin: Two Novel Tiazofurin Analogs. Synthesis, Structure, Antitumor Activity, and Interactions with Inosine Monophosphate Dehydrogenase. J. Med. Chem. 1995, 38, 3829-3837.

[59] Franchetti, P.; Cappellacci, L.; Marchetti, S.; Martini, C.; Costa, B.; Varani, K.; Borea, P. A.; Grifantinia, M. C-Nucleoside Analogues of Furanfurin as Ligands to A1 Adenosine Receptors. Bioorg. Med. Chem. 2000, 8, 2367-2373.

[60] Franchetti, P.; Cappellacci, L.; Perlini, P.; Jayaram, H. N.; Butler, A.; Schneider, B. P.; Collart, F. R.; Huberman, E.; Grifantini, M. Isosteric Analogs of Nicotinamide Adenine Dinucleotide Derived from Furanfurin, Thiophenfurin, and Selenophenfurin as Mammalian Inosine Monophosphate Dehydrogenase (Type I and II) Inhibitors. J. Med. Chem. 1998, 41, 1702-1707.

[61] Kini, G. D.; Hennen, W. J.; Robins, R. K. Synthesis of 2-(4'-Amino-4'-deoxy- $\beta$-Dribofuranosyl)thiazole-4-carboxamide, a Carbon-Linked Nucleoside with a Free Pyrrolidine Sugar. J. Org. Chem. 1986, 51, 4436-4439.

[62] Mironiuk-Puchalska, E.; Koszytkowska-Stawinska, M.; Sas, W.; De Clercq, E.; Naesens, L. Synthesis of Novel AZA-Analogs of Tiazofurin with 2-[5,5-bis(Hydroxymethyl)Pyrrolidin-2-yl] Framework as Sugar Mimic. Nucleosides, Nucleotides 2012, 31, 72-84.

[63] Haraguchi, K.; Matsui, H.; Takami, S.; Tanaka, H. Additive Pummerer Reaction of 3,5-O-(Di-tertbutyl)silylene-4-thiofuranoid Glycal: A High-Yield and b-Selective Entry to 4'Thioribonucleosides. J. Org. Chem. 2009, 74, 2616-2619.

[64] Xiang, Y.; Teng, Q.; Chu, C. K. Novel C-nucleoside analogs of 1,3-dioxolane: Synthesis of enantiomeric (2'R,4'S)- and (2'S,4'R)-2-[4-(hydroxymethyl)-1,3-dioxolan-2-yl]-1,3-thiazol-4carboxamide. Tetrahedron Lett. 1995, 36, 3781-3784.

[65] Cai, D.-M.; Lin, K.-H.; Li, M.-Z.; Wen, J.-W.; Li, H.-Y.; You, T.-P. Synthesis of novel 1,3dioxolane nucleoside analogs. Chin. J. Chem. 2004, 22, 1425-1431.

[66] Qu, F.; Hang, J. H.; Du, J.; Newton, M. G.; Chu, C. K. Asymmetrie Synthesis of (2'R, $\left.4^{\prime} R\right)$ and (2'S,4's)- 1,3-Dioxolanyl Triazole C-Nucleosides. Tetrahedron 1999, 55, 9073-9088.

[67] Cai, D.; Lin, K.; Song, M.; You, T. Ring-Expanded C-Nucleoside Analogues of Tiazofurin. Synth. Commun. 2004, 34, 159-170.

[68] Merino, P.; Tejero, T.; Unzurrunzaga, F. J.; Franco, S.; Chiacchio, U.; Saita, M. G.; Iannazzo, D.; Piperno, A.; Romeo, G. An efficient approach to enantiomeric isoxazolidinyl analogues of tiazofurin based on nitrone cycloadditions. Tetrahedron: Asymmetry 2005, 16, 3865-3876.

[69] Chiacchio, U.; Rescifina, A.; Saita, M. G.; Iannazzo, D.; Romeo, G.; Mates, J. A.; Tejero, T.; Merino, P. Zinc(II) Triflate-Controlled 1,3-Dipolar Cycloadditions of C-(2-Thiazolyl)nitrones: Application to the Synthesis of a Novel Isoxazolidinyl Analog of Tiazofurin. J. Org. Chem. 2005, 70, 8991-9001.

[70] Franchetti, P.; Marchetti, S.; Cappellacci, L.; Jayaram, H. N.; Yalowitz, J. A.; Goldstein, B. M.; Barascut, J.-L.; Dukhan, D.; Imbach, J.-L.; Grifantini, M. Synthesis, Conformational Analysis, and Biological Activity of C-Thioribonucleosides Related to Tiazofurin. J. Med. Chem. 2000, 43, 1264-1270. 
Post-print of Current Trends in Medicinal Chemistry, 2014, 14, 1212-1224 